\title{
LAND TENURE SECURITY AS A MARKET STIMULATOR IN CHINA
}

\author{
JOYCE PALOMAR*
}

\section{CONTENTS}

I. Benefits to China from Land Tenure Security 8

A. Necessity of Land Title Security for a Sustainable Market Economy 8

B. Necessity of Land Title Security to Stimulate Foreign Investment and a Market for Mortgage-Backed Debt

II. Risks to Investors in the Current Chinese Land Title System

A. Risks Involving Land Title Registration

1. Multiple Registry Offices.

2. Incomplete Land Registry Records ..........................................21

3. Vague Notice Requirement ......................................................21

4. Reliance on Title Certificates Rather Than Land

Registry Card

5. Inconsistency in Grant Regulations and Land

Registration Rules

B. Land Descriptions \& Boundaries.................................................2 24

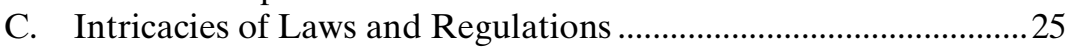

1. Complex System Governing Land Use ....................................26

2. Restrictions on Transfer of Land Use Rights by

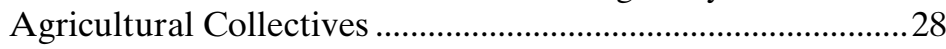

3. Uncertain Rights of Foreign-Investment Enterprises ..............30

4. Risks Involving Leases................................................................30

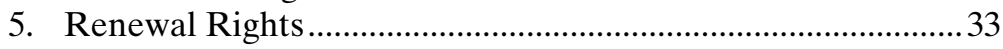

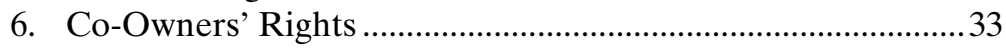

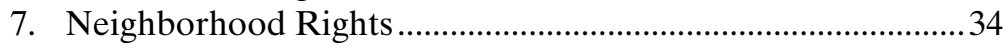

Copyright $($ C by Joyce Palomar

* J.D., University of Nebraska; M.A., University of Nebraska. Judge Haskell A. Holloman Professor of Law and Presidential Professor, University of Oklahoma College of Law. I would like to thank Professors Patrick A. Randolph and Lou Jianbo. Without their clearly written and comprehensive book on Chinese Real Estate Law, I could never have written this Paper. Additionally, without Professor Lou's invitation to present a paper on the law of titles at the University of Beijing's Conference on Chinese Real Property Law, I would not have been led into this research area that is so vital to emerging economies. I also appreciate the encouragement and the insightful comments given by Professors Benito Arrunada, Frances Foster, Dorsey D. Ellis, and John Haley. 


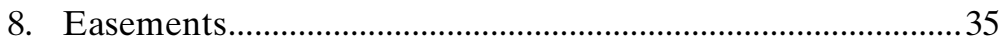

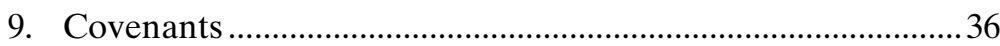

10. Inheritance Laws and Spousal Rights .......................................36

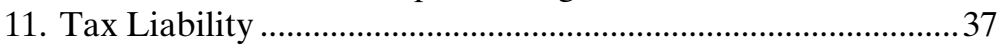

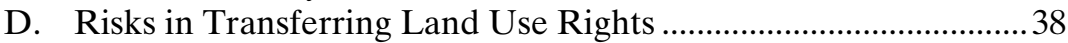

1. Transferability of Granted Land Use Rights............................38

2. Risks in Process of Converting Allocated Land Use Right To Granted Land Use Right..........................................40

3. State's Right to Terminate Land Use Rights.............................. 41

4. Flaws in Process of Setting Land Use Fee ................................. 41

5. Forfeiture of Land Use Right if Use is Not Commenced or Continued

6. Transfers of Allocated Land Use Rights from Educational Institutions, Scientific Research Institutes, Cultural Organizations, Health Institutions, and Political

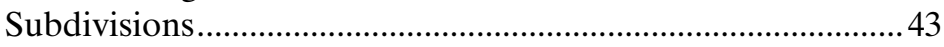

7. Restrictions on Standard Form Contracts ................................4

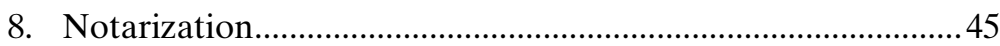

9. Risks Involving Mortgages and Foreclosure ….........................45

10. Dians and Other Creditors' Rights...........................................50

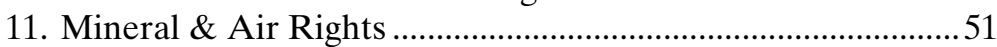

III. Enhanced Land Title Security for Purchasers and Investors in China .

A. Reducing Risks to Land Titles by Legislation and Regulation .53

B. Increasing Land Title Security with Improvements to

China's Land Title Registration System ...........................................56

C. Reducing Risks to Investors In China With Private Land

Title Services and Land Use Rights Insurance

\section{BENEFITS TO CHINA FROM LAND TENURE SECURITY}

\section{A. Necessity of Land Title Security for a Sustainable Market Economy}

Land tenure security is essential to stimulate the development of land. If land tenure is not secure, ${ }^{1}$ both local and foreign investors will be hesitant to invest in land development. Economists and inter-

1. According to commentators, "property's value derives largely from the confidence people place in its security." JEFF GATES, THE OWNERSHIP SOLUTION xxvi (1998). 


\section{national development specialists posit further that land title security ${ }^{2}$ not only stimulates a market for land and its development, but that it is the very foundation of a market economy ${ }^{3}$ and sustainable eco- nomic growth. ${ }^{4}$ Economists and development experts agree that}

2. The distinction between "land title" and "land tenure" as used in this paper is that "title" refers to ownership of an interest in land. One's title may confer full rights in a parcel of land, as in the fee simple absolute recognized in English and American law, or lesser rights in a parcel of land, such as the mere right to possess that a lease or easement confers. Persons with a legal title to land may obtain the law's assistance in enforcing whatever rights are deemed legally to flow from the particular title they hold. In comparison, "land tenure" refers to possession of the land, not necessarily pursuant to a legal ownership right. Depending on the legal, political, and cultural system, such tenure or possession may have rights attached or may be revocable at the will of the titleholder. When one begins to speak of land tenure "rights," one necessarily is speaking of some level of land title. I posit that land titles must be clear and secure before land tenure can be secure.

3. See Hernando de Soto, The Mystery of Capital (2000) [hereinafter De Soto, THE MYSTERY OF CAPITAL]; see also GATES, supra note 1, at xxvi; GERHARD LARSSON, LAND REgistration In DEVEloping Countries, 20 (1991). Mancur Olson writes concerning the creation and sustenance of a market economy:

It is becoming clear that a country cannot obtain a competitive market economy simply by repealing communism and making sure that the government does not interfere with the economy. A thriving market economy does not emerge automatically. It requires institutions that most people in the economically developed democracies unthinkingly take for granted, but that the emerging democracies of Eastern Europe and the societies of Africa, Asia, and Latin America usually do not have.

A thriving market economy apparently requires, among other things, institutions that provide secure individual rights - that insure that individuals, and the firms that they create, can best advance their interests by being as productive as possible and engaging in mutually beneficial trade. The incentives to save and to invest depend upon individual rights to marketable assets-on property rights ....

Even in some of the countries where all the foregoing rights are available, they are not secure. Some dictatorships have, at times, provided individuals with the rights needed for competitive markets and thereby brought about periods of rapid economic growth. Yet the dictators' subjects have not only lacked political freedoms, but also any confidence that their property and contract rights will continue to be respected if the regime, or even the dictator's policy, changes. Thus the market rights do not elicit as much investment and economic advance as would have occurred if everyone were confident that they would last.

Mancur Olson, The IRIS Idea: The Needed Research, Center for Institutional Reform and the Informal Sector, available at http://www.iris.umd.edu/research/neededresearch.asp (2000) (last visited Nov. 23, 2001).

4. Ian Williamson writes:

The pivotal tension of sustainable development is between the environment and the pressures of human activity. It is the system of recognising, controlling and mediating rights, restrictions and responsibilities over land and resources that forms the fulcrum. Thus, "land administration" can and should play an important role in the infrastructure for sustainable development. In this context, "Sustainable development means development that effectively incorporates economic, social, political, conservation and resource management factors in decision-making for development. The challenge of balancing these competing tensions in sophisticated decision making requires access to accurate and relevant information in a readily interactive form." (citations omitted)

A common fault of some LAS [Land Administration System] projects around the world is that they focus on the technical aspects of the project, such as mapping, adjudication, surveying and preparation of titles, and sometimes forget the main objective 
"modern capital markets generate economic growth in part because formalized property rights remove uncertainty, which lowers transaction costs ... . Without formal property [relationships], ... a modern social market economy cannot exist.",

When property rights become secure, citizens can depend upon these rights in participating in private transactions. These transactions further provide individuals incentives to produce goods and services. Economic historians cite the late eighteenth century as an illustration of the relationship between property rights and the emergence of the modern market: "the boom in technological innovation in the West, and the massive investment that made it possible, began only at the end of the eighteenth century, when property rights were perfected and made independent of politics." ${ }^{\circ}$

Economic productivity, like that illustrated above, yields economic cycles. ${ }^{7}$ When land titles and land tenure are secure, landholders may utilize their property rights as collateral for loans. When lenders are confident that their titles or liens against real property collateral will be enforceable, they will accept interests in land as security for loans in amounts up to the fair market value of the property

for the project. Such projects are never about land titling per se, nor should they be. They are about facilitating sustainable development, land markets, social justice, institutional reform, poverty eradication, environmental management or addressing regional income disparities.

Ian P. Williamson, Best Practices for Land Administration Systems in Developing Countries, in INTERNATIONAL CONFERENCE ON LAND POLICY REFORM 6, 17 (2000). Additionally, "land administration and cadastral systems... are not ends in themselves. They support effective land markets, increased agricultural productivity, sustainable economic development, environmental management, political stability and social justice." Id. at 26 (citations omitted).

5. GATES, supra note 1 , at 224, citing HeRnANdo DE Soto, THE OTHER PATH (1989) [hereinafter DE SOTO, THE OTHER PATH]; see also Pitman B. Potter, Globalisation and Local Legal Culture, Dilemmas of China's Use of Liberal Ideals of Private Property Rights, 2 AUSTL. J. AsIAn L. 1, 7 (2000) (citing Richard A. Epstein, Property and Necessity, 13 HARV. J.L. \& Pub. POL'Y 2 (1990)). Among the organizations currently supporting research into practical applications of this theory for emerging economies are the following: World Bank's Land Policy Network; United Nations Development Programme, James Gustave Speth, Administrator; United Nations Food \& Agriculture Organization; Institute of Liberty and Democracy, Hernando de Soto; World Business Council for Sustainable Development, Founder, Stephan Schmidheiny; Center for Institutional Reform and the Informal Sector (IRIS), University of Maryland; Land Tenure Center at the University of Wisconsin; Center for Property Studies at the University of New Brunswick, Canada; The Adam Smith Institute (UK), Dr. Madsen Pirie, President; Center for Ethics, Capital Markets, and Political Economy, John Feldmann, Director; President's Council on Sustainable Development, Ray C. Anderson, Co-chair; Frontiers of Freedom Institute, Chairman Malcolm Wallop; AVINA Foundation, Zurich-based, Stephen Schmidheiny, Founder; Foundation for Enterprise Development; United States Agency for International Development, Walter Coles, Director.

6. See De Soto, The OTher Path, supra note 5, at 177.

7. Id. at 184 . 
interest. Thus, secure land titles and enforceable mortgage rights together create access to significant amounts of capital. ${ }^{8}$ In the United States, for example, seventy percent of the credit extended to new businesses stems from mortgaging real property titles as collateral for loans.' With access to credit, individuals may improve their land, grow crops, establish businesses, hire employees, pay wages, and generate profits. $^{10}$ The standard of living of landowners, business owners, and their employees consequently will improve. ${ }^{11}$ From increased profits and incomes, individuals involved in all sectors will have capital to buy services and products from vendors whose incomes and businesses also will improve commensurately. From the increased incomes, profits, and property values, taxes will be paid, thereby increasing the nation's income. Recent empirical studies in Thailand, ${ }^{12}$ Costa Rica, ${ }^{13}$ and Peru, ${ }^{14}$ comparing the level of investment and productivity on titled and untitled farms, support this hypothesis.

8. Peruvian economist Hernando de Soto has published empirical evidence of how the lack of secure title to land in Peru inhibits economic development. DE SOTO, THE OTHER PATH, supra note 5. Lack of legal title means lack of secure collateral, which means lack of access to credit. De Soto found, conversely, that land development and investment in improvements and technology increased when occupants gained legal title to their land. See also Kerry A. Dolan, Waking Dead Capital, Forbes, May 15, 2000, at 99.

9. GATES, supra note 1, at 223.

10. See generally Tim Hanstad, Designing Land Registration Systems for Developing Countries, 13 AM. U. INT'L L. REV. 647, 702-03 (1998) ("Land registration systems contribute toward solving production, credit, poverty, and employment problems.").

11. "Poverty is cured not with money but by gaining access to the productiveness-the skill and the tools-required to earn money." GATES, supra note 1, at 43 (citing Robert Ashford, The Binary Economics of Louis Kelso: A Democratic Private Property System for Growth and Justice, in Curing World Poverty-The New Role of Property (John H. Miller ed., 1994).

12. See Hanstad, supra note 10, at 658-59 (citing GERSHON FEDER, ET AL., LAND Policies AND FARM PRODUCTIVITY In ThaILAND 28, 94-108, 148-53 (1988)); see also Laurence D. Stifel, Patterns of Land Ownership in Central Thailand During the 20th Century, $64 \mathrm{~J}$. SIAM SOC'Y 1, 237, 237-74 (1976).

13. See Mitchell A. Seligson, Agrarian Reform in Costa Rica: The Impact of the Title Security Program, 35 INTER-AM. ECON. AFF., 31, 31-56 (1982). Nevertheless, cultural, sociological and other factors also are important determinants of whether land titles will be linked to greater productivity. Land registration in Honduras did not seem to stimulate a land market as predicted. Four years after registration, no difference was shown in the rate of land transactions in one titled area compared to the rate of transactions in untitled areas. In fact, fewer parcels of land were transferred in one titled area during a four-year period than in the untitled area. However, the landowners themselves did perceive economic benefits from titling and it simply may be that having title enhanced the owners' interest in utilizing their land and developing it and made them less interested in transferring it for value. Hanstad, supra note 10, at 660, 661 n. 47 .

14. DE Soto, THE OTHER PATH, supra note 5. 
Conversely, when land titles are not secured by law, people cannot easily transfer their property. ${ }^{15}$ They cannot develop it for more valuable purposes or utilize it as collateral for credit. ${ }^{16}$ This limits the productivity of the property and its value as a factor of production. ${ }^{17}$ Effects on the general economy may include the inability to increase

15. Id. at 159 ("[T]he most significant cost of the absence of a good law is the absence of secure, reliable property rights.").

The possession of a title can be an important determinant of the degree of tenure security. [A study of] the impact of land policies on farm productivity in Thailand, showed that the higher the degree of tenure security, the higher the demand for investment, especially for goods and services that become attached to land. Access to the formal credit system is easier for titled farmers because they represent a lower risk for the lending institutions. A larger supply of formal long-term credit (usually cheaper than credit obtained in informal markers) helps to further increase the rate of investment.

Tenure security also increases access to short-term credit, which in turn leads to greater use of variable inputs. Consequently, output per hectare, the price of land, and income are higher for titled farmers.

A relevant consideration is often the probability of eviction. The lower this probability, the greater the incentive for farmers to invest in land-attached improvements and for the formal credit system to extend credit. In regions where tenure insecurity is pervasive, the price of land will not reflect the present value of the income stream associated with the exploitation of land for agricultural production because not all land rights are legitimate or enforceable under the law ....

Tenure insecurity also precludes "landowners" in the urban sector from using this preferred form of collateral in the formal credit market. As in agriculture, it can be a binding constraint for potential borrowers, particularly for the more financially fragile. Similarly, tenure insecurity reduces the incentive to invest, especially in land-attached improvements. The capital-to-land ratio in the housing sector will accordingly be lower than otherwise. In peri-urban areas lack of tenure security is widespread, and so the incentive for investment will be reduced. In addition, ... tenure insecurity reduces the demand for house improvements and government services.

Antônio Salazar P. Brandão \& Gershon Feder, Regulatory Policies and Reform: The Case of Land Markets, in Regulatory Policies AND Reform: A Comparative Perspective 191, 195-96 (Claudio Frischtek ed., 1995) (citations omitted).

16. See id; see also Brian Schwarzwalder, Land Registration, in LEGAL IMPEDIMENTS TO EFFECTIVE RURAL LAND RELATIONS IN EASTERn EuRope AND CENTRAL ASIA, A COMPARATIVE Perspective, WORLd BANK TechnicAl PAPER No. 436, at 165 (Roy Prosterman \& Tim Hanstad eds., 1999) (commenting that when land transfers are made before a legal framework has been created for ownership of interests in land, its transfer and assurance of ownership rights, the legal results will be unclear). For example, a federal law on registration of rights to land has not yet been adopted in the Kyrgyz Republic in Eastern Europe. Id. at 166. Thus, registration of sales, bequests, gifts, mortgages and other transactions between private parties is not occurring in the countryside. The lack of a legally based, functioning system for recording or registering public land titles increases transaction costs. "[F]armers who mortgage their land are required to submit stacks of paperwork, which they must gather from many different sources." Id. To address this problem, Moldova recently enacted law providing for the creation of a national system of county-level registration offices that will register all legal rights in land. Id. However, it is estimated that the system will require several years to become fully functioning. In the interim period, uncertainty about titles that have been registered and about titles conveyed without using the new procedures for registering land transactions is expected to slow the development of a market for land. $I d$.

17. DE SOTO, THE OTHER PATH, supra note 5, at 159. 
productivity or investments, more expensive capital, an inefficient tax system, and perhaps other negative effects on a nation's development. ${ }^{18}$ According to Hernando de Soto:

If [occupiers of land who do not have legal title] cannot enforce their rights to land, housing, and equipment, their incentives for investing in them are considerably reduced. People build less if they think there is a risk that the state or another person might take away or occupy what they have built .... The effect of all this is to reduce aggregate investment.

Secure property rights, on the other hand, encourage holders to invest in their property because of their certainty that the property will not be usurped. From a strictly economic standpoint, therefore, the true purpose of property rights is not to benefit the individuals or entities holding those rights, but to give them the incentive to increase the value of their assets by investing, innovating, or combining them advantageously with other resources, something which would have beneficial results for society. ${ }^{19}$

B. Necessity of Land Title Security to Stimulate Foreign Investment and a Market for Mortgage-Backed Debt

As Section A describes, secure land titles may give landowners access to credit and capital. The land title security provided by a nation's public land title registration system may be sufficient to encourage mortgage loans from local banks and mortgage lenders. In addition, emerging economies may benefit in at least two more ways if land titles are sufficiently secure to attract foreign investors. First, foreign investors willing to build factories and conduct business in developing countries bring new capital into the emerging economy and provide employment and tax revenue that will further economic growth. In order for investors to be willing to either invest money in land development in China or accept borrowers' land in China as collateral for loans, investors must believe that their investments are secure. As described by a leading authority, "[f]oreign investors seek the risk-reducing characteristics that make up the rule of law. Legal authority, certainty, generality, congruity, enforcement, and a viable legal profession are all prerequisites to managing investment risk." ${ }^{20}$

18. Id. at $175-77$ (suggesting that other effects can be limited technological progress, increased utility rates, and difficulties in formulating macroeconomic policy).

19. Id. at $159-60$.

20. David J. Bledsoe \& Roy L. Prosterman, Policy, the Rule of Law, and Rural Land Reform in China, in RDI REPORTS ON FOREIGN AID AND DEVELOPMENT \#101, at 7 (2000) (citing Douglas Webb, Legal System Reform and Private Sector Development in Developing Countries, 
When investing in projects that involve land development or land use, foreign investors must be certain that the land can be developed and utilized according to their plans. Further, when accepting real property interests as collateral for loans, foreign investors must be confident that the right to the real property will be available to satisfy the debt.

Second, if mortgage liens are sufficiently secure, interests in the repayment of mortgage-backed debt may be sold in the world's securities markets, unlocking a source of capital that otherwise would not be available for investment in China. In the United States, debt backed by mortgages are being securitized, i.e. interests in the repayment of large mortgage-backed loans or large pools of smaller mortgage-backed loans are being sold as securities both directly to large institutional investors and indirectly to individuals who invest in mutual funds that hold shares in real estate investment trusts. ${ }^{21}$ This secondary market for mortgage-backed loans is important because local development need not depend solely on the availability of funds in that locality. Local lenders may trade their long-term mortgage loans in the securities market for new capital that then can be lent to new borrowers. Those mortgage loans, in turn, can be sold by the local lender in the securities market for new capital that, in turn, will be lent to new borrowers, yielding a steady source of funding for home purchases and property development. The money that investors have poured into the secondary mortgage market has been credited with, first, creating a consistent flow of funds for home loans in the United States since the mid-1940s, ${ }^{22}$ and second, stimulating the boom in commercial real estate development in the $1990 \mathrm{~s}^{23}$

For mortgage-backed securities to be rated highly by rating agencies and to be sponsored by recognized investment banks, each mortgage lien must be valid and enforceable. ${ }^{24}$ An active secondary market for mortgage loans is created only if investors believe that mortgage-backed loans are relatively safe in comparison to their yield. In the United States, lenders in the 1940s began routinely to require private title insurance on each first mortgage lien in order to make their mortgages sufficiently secure for investors in the secon-

in Economic DeVelopment, Foreign InVESTMENT AND the LAW 45, 45-65 (Robert Pritchard ed., 1996)).

21. Joyce Palomar, Title Insurance Law, § 1.01[2] \& ch. 19.0 (Supp. 2000).

22. $I d$.

23. $I d$.

24. Id. at ch. 19.0. 
dary mortgage market. ${ }^{25}$ In Europe, even though private property ownership has a long, solid history and conclusive land title registration systems exist, one commentator advises:

Rating agencies have become more responsive concerning title insurance and its role in the securitization process. It is not yet included among their rating criteria, but it would not be overly speculative to predict that it will be in due course and those lenders with title insured books will have a substantial edge. ${ }^{26}$

Similarly, in Australia and New Zealand, which also have both a long history of private property ownership and conclusive land title registration systems, Standard \& Poor's credit analysts now recommend that a private title insurance product cover first mortgage liens sold into the securities market. ${ }^{27}$ Standard \& Poor's analysts posit that the standard title examination and documentation processes, risk elimination features, and private indemnity contracts provided by title insurance will enhance the security of the mortgage liens and the creditworthiness of the securities. ${ }^{28}$

Thus, enhancing the land title security that the rule of law and a public registration system provides with the risk reduction and promise of indemnification offered by private insurance, may increase foreign investment and demand for China's mortgage-backed debt in the securities markets. Absent the ability to reduce risks and offer indemnification against losses, foreign investment and capital for mortgage loans may be slowed by the fear of unknown risks inherent in China's untested land laws and registration system.

25. The title insurance policy obtained by a mortgage lender continues to cover assignees or successors in ownership of the indebtedness. Id. § 4.04[2] \& App. E-6, ALTA Loan Policy (10/1992), Conditions \& Stipulations I[1(a)(i).

26. Fredrick M. Kerr, Title Insurance and the European Markets, TITLE NEws, Jan./Feb. 2001, at 20, 22.

27. Fabienne Michaux \& Peter Gibson, Title Insurance in Australian and New Zealand RMBS Transactions, available at http://www.standardandpoors.com/ResourceCenter/Ratings Criteria/StructuredFinance/articles/169743f.htm (last visited Nov. 23, 2001). The authors write:

Standard \& Poor's, an objective credit analysis organization, posits that title insurance can provide a level of assurance to lenders, which is no less than that provided by traditional due diligence processes in the Australian and New Zealand markets, and which, in some circumstances, can offer lenders a significantly greater degree of risk protection.

28. Title insurance developed in the United States initially because of risks existing in the United States' system of voluntary recordation of title evidence and the grantor-grantee indexes used in most county offices to access land title records. In countries with conclusive registration systems, particularly in those where the government provides a compensation fund for those damaged by the registrar's errors or negligence, purchasers and lenders had not considered private title insurance to be as necessary. However, the desire of American rating agencies and investment banks for credit enhancement may change that custom in any country where first mortgage liens are to be securitized and sold to American investors. 


\section{RISKS TO INVESTORS IN THE CURRENT CHINESE LAND TITLE SYSTEM}

In 1988, as part of the government's goal of establishing market transactions, China amended its Constitution and Land Administration Law to permit the transfer of "land use rights" to private persons and entities. ${ }^{29}$ In 1990, China enacted regulations allowing the conveyance of long-term land use rights to businesses for the purpose of development. ${ }^{30}$ New land registration rules also were enacted. ${ }^{31}$ To further promote the development of a market for real estate, the National People's Congress promulgated additional laws for the administration of urban real estate in $1994 .^{32}$

Though the State may transfer "land use rights" to private persons and entities, the right of ownership of the land remains vested in either the State or an Agricultural Collective. The land use rights transferred may be "granted land use rights" provided in exchange for value for specific terms of years to domestic or foreign corpora-

29. Xianfa [Constitution], art. 10, sec. 4 (amended 1988) (P.R.C.) ("Land use rights may be assigned in accordance with the laws and regulations."), translated in ISABELLE I. H. Wan, Zhang Pu, Jesse T. H. Chang \& Philip Qu, A Professional's Guide to P.R.C. LAND Legislation 103 (1999); see also Law of the Peoples' Republic of China on Land Administration, ch. 1, art. 2 (amended 1988, 1998) [hereinafter Land Law], translated in WAN ET AL., supra note 29, at 2041 ("Land use rights may be assigned according to law."). In this Article, I have used the English translations of China's Constitution [XIANFA], laws, and regulations found in id. See also Potter, supra note 5, at 12; PATrick A. RANDOLPH, JR. \& LOU JiAnbo, Chinese Real Estate Law, 125 (2000); Donald C. Clarke \& Nicholas C. Howson, Developing P.R.C. Property and Real Estate Law: Revised Land Registration Rules, 18 No. 4 E. AsIAN EXECUTIVE REP. 12 (Apr. 15, 1996). Pursuant to the Law of 1994, "[a] land use right granted by the state can be transferred in the market as property .... [Land use rights] also can be leased and mortgaged." CAO Pei, Real Estate Law in ChinA, 65 (1998). The Several Regulations On Definition Of Land Ownership And Land Use Rights, National Land Administration Bureau, (May 1, 1995) and the Regulations on the Implementation of the Land Administration Law of the People's Republic of China, State Council, (Jan. 4, 1991) define the aforementioned property rights over land in China.

30. Provisional Regulations of the People's Republic of China Regarding the Grant and Assignment of State-Owned Land Use Rights in Urban Areas, (1990) [hereinafter Prov. Reg. Land Grant and Assignment], translated in WAN ET AL., supra note 29, at 2097; see also Provisional Regulations for Administration of Foreign Investment in Development and Operation of Tracts of Land (1990), translated in WAN ET AL., supra note 29, at 2109-14.

31. See Implementing Rules for the Law of the People's Republic of China on Land Administration, (1998) [hereinafter Land Law Implementing Rules], translated in WAN ET AL., supra note 29, at 2083-96; Rules on Land Registration, State Land Administration (1995) [hereinafter Rules on Land Reg.], translated in WAN ET AL., supra note 29, at 2121-40; see also Potter, supra note 5, at 12 .

32. PEI, supra note 29 , at 32. 
tions, enterprises, other entities, and individuals. ${ }^{33}$ Alternatively, the State may convey "allocated land use rights," which are rights to use and occupy land for designated public purposes without payment of value, other than a small annual tax or "land use fee." ${ }^{34}$ In general, holders of granted land use rights may sell, lease, mortgage or otherwise transfer them. ${ }^{35}$ Conversely, holders of allocated land use rights may not transfer them, unless the holder first receives the State's permission to convert the allocated land use right to a granted land use right. ${ }^{36}$

With these new rights have come new uncertainties and new risks. Recent newspapers have reported on the instability that has accompanied the Chinese government's effort to secure land tenure.

[I]n Beijing, McDonald's signed a 20-year lease agreement for what was the world's largest McDonald's . . . . However in December 1995, 2 years into the lease, McDonald's noticed bulldozers leveling the structures adjacent to the 'Great Palace'. To their chagrin, Hong Kong-based Li Ka Shing, one of the world's wealthiest men, was backing a commercial-residential redevelopment site two blocks away from Tianammen Square and this meant Ronald had to pack his McNuggets and leave. Industry experts say that McDonald's should more or less accept this as a "part of doing business in a country whose rulers have placed a higher emphasis on rapid redevelopment than on contractual niceties." Though they complained quite publicly and managed to get a weak promise from the administration to receive a future comparable site, McDonald's appears to understand that this is the risk of doing business in China ....

33. Law of the People's Republic of China for the Administration of Urban Real Estate, 8th Sess. of 8th National People's Congress, ch. 2, § 1, art. 7 (adopted July 5, 1994, effective Jan. 1, 1995) [hereinafter Urban Real Estate Law], translated in WAN ET AL., supra note 29, at 206061; Prov. Reg. Land Grant and Assignment, ch. II (1990), supra note 30, at 2109-10; RANDOLPH \& LoU, supra note 29, at 132; Clarke \& Howson, supra note 29, at 12.

34. Urban Real Estate Law, ch. 2, §2, art. 22, supra note 33, at 2064; Provisional Regulations Governing Allocated Land Use Rights, Decree No. 1, State Land Administration (1992), translated in WAN ET AL., supra note 29, Release \#2 2001, at 2141 [hereinafter Prov. Reg. Gov'g Land Use Rights ]; Clarke and Howson, supra note 29, at 12.

35. Urban Real Estate Law, ch. 4, supra note 33, at 2066-72.

36. Id.; Prov. Reg. Gov'g Land Use Rights, supra note 34; see also Prov. Reg. Land Grant and Assignment, ch. VII, art. 44 \& 45, supra note 30, at 2105.

37. Ian Hunter, Big Mac in China: And the Cattle Grew Restless, AnOMAlies ProJect (Stockholm School of Economics \& European Institute of Japanese Studies 1997), available at http://www.hhs.se/eijs/ anomaly/CBigMac.htm (last visited Nov. 23, 2001) (footnote omitted). The Asian Wall Street Journal reported that McDonald's China Development Company President, Marvin Whaley, considers its "continuing tussle with central and Beijing government officials over the fate of its flagship restaurant on the corner of Beijing's busiest shipping street" to be no more than a "bump on the road." 
China Daily reported several bribery cases involving the procurement of land use rights. One involved Chen Jinlai, the "former deputy director of the local land administration department in Bao'an County in Shenzhen." "38 Jinlai, in exchange for "illegally giving land-using rights to some companies," received "bribes of 480,000 yuan $(\$ 55,000), \operatorname{HK} \$ 80,000(\$ 10,400)$ and shares valued at 10,000 yuan $(\$ 1,150) ., 39$

Another well-publicized lawsuit in Beijing involved property rights. A homeowner sued the Beijing district's cultural department when the department did not "put his [350 year old traditional courtyard house] on its list of protected properties." He also sued "the district housing office for refusing to compensate him for land-use rights that he said they were depriving him." The suit did not stop the government's demolition of the house. The Beijing government reportedly offered the plaintiff "the equivalent of $\$ 750$ a square meter compensation, but it stands to receive about [ten] times that amount from the bank that is building on his site."

The remainder of this section identifies specific risks to owners' ability to utilize their land use rights and to lenders' ability to realize the value of their real property collateral that exist under China's current real estate laws and title registration system. ${ }^{41}$ Some of these risks are the result of lack of enforcement of current law; other risks exist because the law is unclear or ambiguous. A few risks exist be-

Mr. Whaley says the media may have mistakenly overblown what is essentially a commercial and urban-planning decision into a soap opera pitting foreign business against the Chinese government and a Hong Kong billionaire. He says McDonald's fully expects to give way to progress and knows it will receive an equitable settlement. "Things are very complicated in China because they're trying to do so much," he says.

"We'll come to an agreement that is suitable for us and suitable for them. We have a very good working relationship with the city. They'll compensate us."

McDonald's Can Smell Success in China, AsiAn WALL ST. J., Dec. 3, 1995, available at http:// www.mcspotlight.org/media/press/asian_3dec95.html.

38. Shenghen Nets Nation's Largest Bribery Case, China DaILy News, July 16, 1994, 1994 WL 10759688; Another recent story involving corruption in land deals in Shenzhen appeared in London's Financial Times:

Chinese investigators are working on one of the most serious corruption scandals . .

Mr. Wang, who headed the Shenzhen city construction and land bureau for several years, is believed to have approved several billion US dollars' worth of construction projects undertaken by local and foreign companies. Investigators think that he may have taken bribes and illegally fixed land deals for developers, officials said.

James Kynge, Shenzen Hit by Corruption Scandal, FinANCIAL Times (London), July 17, 2000, at 8 .

39. ChINA DAILY NEWS, supra note 38.

40. Ian Johnson, House Demolition Marks the End to Suit, AsIAn Wall St. J., Oct. 27, 2000 , at 4 .

41. I do not contend that section II includes all potential title risks. 
cause the law has made a conscious choice in balancing the interests of the public against those of individual owners of land use rights, or in balancing the interests of one individual land use right owner against those of another. Regardless of the reason, risks of loss to investors still can be recognized and reduced, in order to stimulate investment. The means of risk-reduction will differ depending on the reason for the risk.

Section III of this Article recommends means of reducing these risks. Sections III.A. and III.B., respectively, describe ways that the government of China could reduce title risks to purchasers, lenders, and investors by legislation and by improvements to China's land registration system. Section III.C. then considers whether title risks to purchasers, lenders, and investors may be reduced by private land title services and indemnity contracts.

\section{A. Risks Involving Land Title Registration}

After the 1988 amendments to the Chinese Constitution incorporated the legal concept of transferable granted land use rights into Chinese law, ${ }^{42}$ the State Land Administration promulgated rules to provide for a uniform system of registering interests in land. ${ }^{43}$ An in rem right in a land use right arises only upon registration of the right. ${ }^{44}$ Registration legally creates the real property interest. ${ }^{45}$

Agricultural Collective land ownership, land use rights on both State-owned land and Agricultural Collective-owned land, and building ownership all must be registered. ${ }^{46}$ Also, other real estate in-

42. See XiAnFA [CONSTITUTION], art. 10, sec. 4, (amended 1988), translated in WAN ET AL., supra note 29, at 103; see also RANDOLPH \& LOU, supra note 29, at 19.

43. See Land Law Implementing Rules, supra note 31, at 2083-96; Rules on Land Reg., supra note 31, at 2121-40. Although land title registration began in China after the 1949 revolution, it was stopped later by revolutionary campaigns. PEI, supra note 29, at 108. In the 1980s, the current system for land and housing registration was re-established. Id. It was intended to bring the records on property ownership status up to date, "confirm legal titles for property owners," "define the new private property rights introduced by the reforms," and provide the records of title deeds and related instruments for public examination. Id. "Land registration was tentatively [re-]introduced in three cities in 1987, and gradually extended nationally." Id.

44. RANDOLPH \& LOU, supra note 29 , at 44.

45. See Land Law, ch. 2, art. 13, supra note 29, at 2088; see Rules on Land Reg., supra note 31, at 2121-40; see also RANDOLPH \& LOU, supra note 29, at 159-60 ("If a seller contracts with A to transfer the real property, and later registers a transfer to another, B, the transfer to B is good. This is true even if B had knowledge of the contract with A. It is even true if the seller has purported to effect some kind of delivery of possession or instruments to A, but there is no registration of A's interest.").

46. See Rules on Land Reg., supra note 31, at 2121-40. 
terests such as mortgages, leaseholds on land use rights or building ownership, and dians ${ }^{47}$ on urban buildings must be registered. ${ }^{48}$

1. Multiple Registry Offices. Under the current system, Land Administration Bureaus (LAB) "at or above the county level" are in charge of the registration of land use rights. ${ }^{49}$ However, 1996 revisions to the Land Registration Rules confer upon LABs the responsibility for registering lands titles "at the county level and above." This prescription likely means only that if no land registry office exists at the county level in a particular locale, then land use rights for that locale will be registered by the next, higher level of government. Yet, an issue may arise if some documents relating to land use rights on a particular parcel of land are registered at an LAB office at a level above the county level and others pertaining to that same parcel are somehow registered at the county-level LAB.

A second system exists for the registration of interests in buildings, including ownership, leasehold interests, ${ }^{51}$ mortgages, ${ }^{52}$ and other security interests. ${ }^{53}$ The building administrations at or above the county level are in charge of registration and certificate issuance for ownership of buildings and interests in buildings. ${ }^{54}$ A title risk exists if an owner registers ownership of a building, but fails to register simultaneously an ownership interest in the land use right to the land under and around the building. ${ }^{55}$ The 1998 Building Registration Measures provide that the applicant for the registration of building ownership

47. See infra section II.D.10 for a discussion of dians.

48. Rules on Land Reg., ch. I, art. 2 \& 3, supra note 31, at 2121-22; RANDOLPH \& LOU, supra note 29 , at 161 .

49. Land Law, ch. 2, art. 11, supra note 29, at 2044; Urban Real Estate Law, ch. 5, art. 60, supra note 33, at 2122; Rules on Land Reg., ch. 1, arts. 4, 7, supra note 31, at 23.

50. Clarke \& Howson, supra note 29, at 15 (emphasis added).

51. Procedures for the Administration of the Leasing of Premises in Urban Areas, Decree No. 43, Peoples' Republic of China Ministry of Construction, Part III (May 9, 1995), translated in WAN ET AL., supra note 29, at 2160-61.

52. Registration is required for the creation, release, or modification of a mortgage. A mortgage on a land use right is not effective without registration and "will not be protected by law.” RANDOLPH \& LOU, supra note 29, at 168. Thus, if a lender lends to A, and A agrees to register a mortgage securing that loan and fails to do so, the lender has a credit right for the money but has no security interest in A's land and cannot have the loan enforced against the land. A mortgage cannot be created by the transfer or pledge of the certificate of the land use right it encumbers. The certificate is not the legal title to the land. Id. at 167-68.

53. Id. at 162 .

54. Urban Real Estate Law, ch. 4, art. 31, \& ch. 5, art. 60, supra note 33, at 2066, 2073; RANDOLPH \& LOU, supra note 29, at 163.

55. RANDOLPH \& LOU, supra note 29 , at 170. 
must also be the owner of the land use right to the land the building occupies. ${ }^{56}$ In some cities, such as Shanghai, Shenzhen, Beijing, Chongqing, and other business centers, the registration records for buildings and land use rights are maintained together. ${ }^{57}$ In other locations, however, they are maintained in separate offices, creating additional inefficiency and difficulty in determining whether a purchaser, lender, or investor may acquire a right to the building. ${ }^{58}$

2. Incomplete Land Registry Records. In 1990, the State adopted a five-year plan that aimed to have eighty percent of land registered by $1995 .^{59}$ Reportedly, land registry offices in major cities such as Shenzhen, Beijing, Fuzhou, Guangzhou, Xiamen, and Shanghai are staffed and running efficiently. Outside these major cities, however, this is not the case. In some counties, land registry offices have not yet been opened, are not consistently staffed, or are not sufficiently equipped. Where no county registry office is available, parties are supposed to register interests at the LAB "above county level," but a lack of information and transportation may make this difficult.

In addition, "regular and effective access to the registration records may not be a practical reality in some areas unless the party seeking such access has guanxi [a connection]. ${ }^{60}$ Further difficulties may include poor organization of the records and access fees. ${ }^{61}$

Such obstacles discourage registration of land use rights, building rights, and other interests. If registration is hindered and records are incomplete, investors risk claims by unknown parties of unknown interests. Furthermore, while the registry theoretically should be conclusive, it is uncertain whether that rule will be enforced if registration effectively is unavailable to large numbers of people.

3. Vague Notice Requirement. When an application for the initial registration of a land use right is submitted to the Land Administration Bureau (LAB), the LAB first examines the application and related documents. Next, the Bureau publishes a notice describing the rights being registered and allows a period of time for others to

56. Urban Real Estate Law, ch. 4, art. 31, supra note 33, at 2122-23; RANDOLPH \& LOU, supra note 29 , at 170 .

57. RANDOLPH \& LOU, supra note 29 , at 170.

58. Id.

59. PEI, supra note 29, at 108.

60. RANDOLPH \& LOU, supra note 29 , at 166.

61. Id. at 166 . 
object or assert their own claims. ${ }^{62}$ If this period passes without the filing of any adverse claim, the LAB will register the title. ${ }^{63}$ A significant omission in the Rules is that they do not indicate either where or how the required notice is to be published or the length of the objection period. ${ }^{64}$ Is the registration itself conclusive as to the reasonableness of the notice and the sufficiency of the period for objection? If a land use right was registered shortly after application was made without a reasonable attempt to notify possible claimants, will a court uphold the registry?

Subsequent purchasers and mortgagees need assurance that land use rights can be acquired free of the risk of adverse claims. Land use rights would be more secure if the law expressly described a specific time period for objections and outlined the legally sufficient means of giving notice.

4. Reliance on Title Certificates Rather Than Land Registry Card. The registry office prepares both a registration card (tudi dengji $\mathrm{ka}$ ) that is maintained in the registry office and a registration certificate that is given to the transferee. ${ }^{65}$ The card, and not the certificate, constitutes the official registration and legal basis (falu yiju) of the title. ${ }^{66}$ Thus, a purchaser, lessee, mortgagee, or other investor cannot rely upon the transferor's production of a certificate of title. ${ }^{67}$ The certificate is merely a copy (fuben) of part of the contents of the land registration card. ${ }^{68}$ Until the transferee's transfer documents have been accepted by the land registry office for an amended registration, the transferee cannot be certain that the transferor legally held transferable land use rights. ${ }^{69}$

Because of the difficulties with access to land registry offices and records described in section II.A.2, some transferees may choose to rely on seeing a transferor's copy of the certificate of registration rather than verifying the status of title on the card at the land registry office. This would be a risk, since it is the card that establishes the legal title and not the certificate. Persons who no longer have an inter-

\footnotetext{
62. Rules on Land Reg., ch. II, arts. 14, 15, supra note 31, at 2125.

63. Id. at 2126

64. Clarke \& Howson, supra note 29 , at 14.

65. Rules on Land Reg., ch. VII, art. 65 (State Land Administration 1995), supra note 31,

66. Id.

67. RANDOLPH \& LOU, supra note 29 , at 165 .

68. Clarke \& Howson, supra note 29 , at 14.

69. RANDOLPH \& LOU, supra note 29 , at 165.
} at 2136 . 
est in the land may still possess obsolete land use right or building certificates. For example, although the peasants do not own any land now, some still hold land and building certificates issued to them by the Ministry of Internal Affairs under the Agrarian Reform of the 1950s. ${ }^{70}$ These obsolete certificates still are offered as evidence of the scope of ownership of a particular Agricultural Collective or a peasant's house ownership or homestead rights. ${ }^{71}$

Because of the difficulty in obtaining access to valid registration records, some mortgagees have taken possession of land certificates, rather than checking the land registration card in the registry office as evidence of ownership. ${ }^{72}$ Unfortunately, as explained above, it is not safe for the mortgagee simply to hold the land use right certificate. ${ }^{73}$ An unregistered mortgage transaction does not create even a credit right. $^{74}$ Thus, mortgagees must find ways to check the actual registry before giving a loan and then must register their mortgages. ${ }^{75}$

\section{Inconsistency in Grant Regulations and Land Registration} Rules. The Land Registration Rules that China promulgated in 1995 provide for one particular procedure that seems inconsistent with the 1990 Grant Regulations. ${ }^{76}$ The Grant Regulations require that the grant fee must be paid in full within sixty days of the execution of the relevant grant contract. ${ }^{77}$ Yet the Land Registration Rules provide that periodic payments may be made in connection with tract development projects on State-owned land, permitting the grantee to apply within thirty days of paying each installment for registration of additional land use rights. ${ }^{78}$ As a result, a land user who executed a grant contract with respect to five parcels of land, but paid a land grant fee within the sixty-day limit only with respect to parcels one and two, faces uncertainty as to whether he will be deemed to hold real rights or only contract rights to parcels three, four, and five. ${ }^{79}$ According to the Grant Regulations, such person has no in rem right to parcels three, four, and five and no right to a Land Use Rights Certificate for

70. Id. at 78

71. Id. at $78-79$.

72. Id. at 168 .

73. See id.

74. See id.

75. Id.

76. Clarke \& Howson, supra note 29, at 9, 16.

77. Prov. Reg. Land Grant and Assignment, ch. II, art. 14, supra note 30, at 2099-2100.

78. Rules on Land Reg., ch. III, art. 26 (State Land Administration), supra note 31, at 2128.

79. Clarke \& Howson, supra note 29 , at 9,16 . 
those parcels. ${ }^{80}$ The Rules, on the other hand, appear to recognize a kind of option over the remaining tracts, subject only to subsequent payments and registration. $^{81}$

\section{B. Land Descriptions \& Boundaries}

China does not have a universal survey system. ${ }^{82}$ Property descriptions often use monuments such as local roads, buildings, or other features as beginning points for descriptions of the land. ${ }^{83}$ When land descriptions are inadequate, interests in the same land could be registered under different land descriptions and, consequently, purchasers and other investors may not be able to rely on the land registry. Under China's current law, the registration of a land use right establishes the priority of the right. If, however, a transfer or mortgage was registered under one land description, it is unclear whether it would defeat a subsequent registration of a transfer or mortgage filed under another, more accurate description of the same land.

With the resurrection of China's land registration system, the Building Administration has begun to conduct a survey each time someone applies to register rights to a building. ${ }^{84}$ The possibility of conflicting survey maps registered in different locations poses a risk to investors. As section II.A.3 discusses, the registration records for buildings and land use rights are maintained in separate offices, ${ }^{85}$ in all but major Chinese cities. ${ }^{86}$ Thus, the Building Administration could have registered a survey with an application to register rights to the building, while the Ministry of Land and Resources could have registered a survey of the land use right underlying the building when the certificate for the land use right was issued. ${ }^{87}$

No clear method exists to decide boundary disputes when private monuments that delineate boundaries have been eliminated or obscured. Some scholars have suggested treating the disputed area as

80. Id.

81. Id.

82. RANDOLPH \& LOU, supra note 29 , at 173

83. Id.

84. Id. at 174.

85. Id.; Urban Real Estate Law, ch. 5, art. 60, supra note 33, at 2073.

86. For example, registration records for buildings and land use rights are maintained in a single office in Shangai, Shenzhen, Beijing, Chongqing, and other business centers. RANDOLPH \& LOU, supra note 29, at 170.

87. Id. 
co-owned and permitting all claimants to utilize the disputed area. ${ }^{88}$ This result certainly would interfere with purchasers and lenders' investment-backed expectations. Another possible solution that has been utilized in parts of Eastern Europe, and that also avoids the costs associated with surveying each parcel of land, is registering the title according to the physical possession of the land. ${ }^{89}$

Purchasers or investors could lose rights to some of their land to a party in possession, even if that party's rights were not registered. Chinese law does not generally recognize the concept of adverse possession. $^{90}$ Nevertheless, if registration records are unclear, a few recent statutes have begun to permit possession to be used to resolve boundary disputes and clarify registration records. ${ }^{91}$ Additionally, Chinese civil law does recognize the concept of laches, which could be applied to create a right in a possessor of land if the registered owner failed to object for a significant period of time. ${ }^{92}$ Alternatively, even where the registered owner is awarded the right to the property, if the possessor occupied and improved the property in good faith, the court could order the registered owner to compensate the innocent possessor for the value of the improvements. ${ }^{93}$

\section{Intricacies of Laws and Regulations}

An investor in any nation wants certainty that land being purchased or accepted as collateral for a loan may be utilized for the purpose for which the financial investment is made. The investor wants assurance that the development plans comply with all laws, land use plans and regulations that affect the property. A foreign investor risks interpreting intricate laws and regulations in one way, only to find that officials in the jurisdiction in which the land is located have a different interpretation. Most risks to the building and land use rights of purchasers, lessees, lenders, and other investors in China result from uncertainties concerning the interpretation, construction, and application of laws and regulations.

In some cases, China's current laws and regulations do not define clearly the consequences of a violation. For example, although regu-

88. Id. at 320 .

89. For a general discussion of land registration systems in Eastern Europe, see Schwarzwalder, supra note 16.

90. RANDOLPH \& LOU, supra note 29, at 174.

91. Id.

92. $I d$.

93. Id. 
lations require real property development companies to register documents with the local Housing Administration Bureau within three months of the sale of a new building or a proposed building, ${ }^{94}$ no consequence is stated for failure to comply. Will a fine merely be imposed, or will the building project be halted, or is the transfer void? Many laws and rules provide for deadlines and time limits, but do not indicate the consequences of any failure to meet those time limits. Other rules imply consequences, but do not expressly state them. For instance, in China's land registration system, if rights are not raised during the designated period for objection, ${ }^{95}$ one might assume they are extinguished. But no law or regulation states this explicitly. Also, Article 65 of the Rules on Land Registration makes the Land Registration Card the legal basis of ownership of land, land use rights, and other interests in land. ${ }^{96}$ Under the policy of most land registration systems, this card is to be conclusive as to title and may be relied upon even if later proved erroneous. If this is the policy, however, it should be stated expressly. In England, Canada, and Mexico, courts have carved out exceptions to this rule in the name of equity. In China, it is unclear whether a court would uphold title as it is stated on the Land Registration Card even if equity would suggest another result. ${ }^{97}$

The sections below discuss particular Chinese laws and regulations that yield uncertain results and create specific risks.

1. Complex System Governing Land Use. In China, a series of complex administrative systems guide land use decisions. ${ }^{98}$ These include the Comprehensive Land Use Planning System, Annual Land Use Planning System, Urban Zoning System, Arable Land Protection System, and the National Land Administration Information System (which includes the Land Survey System and the Land Statistics System). ${ }^{99}$

The Chinese government establishes land use guidelines and procedures that customarily are carried out at the provincial or local level. ${ }^{100}$ Additionally, the Zoning Administration in each province has

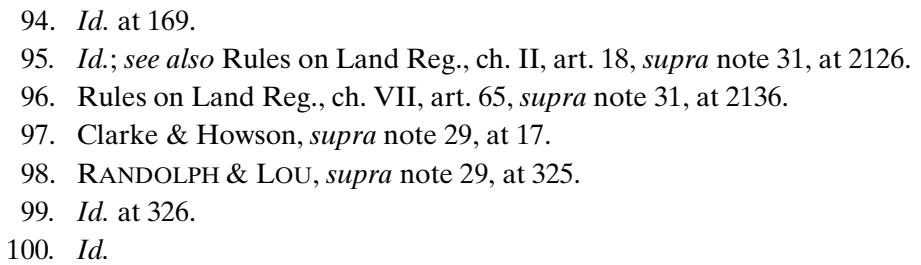


the right to adopt guidelines within each province, as cities do within each city. ${ }^{101}$ In large cities, independent zoning plans may be drafted for individual districts of the city. ${ }^{102}$ Cities also may include the surrounding suburbs in their land use plans. ${ }^{103}$ All these zoning plans govern the issuance of land use rights and building permits, as well as the regulation of land development. ${ }^{104}$

The construction of buildings and infrastructure on land use rights must comply with the Law on Administration of Urban Real Estate ${ }^{105}$ as well as with the comprehensive land use plan, annual land use plan, annual real estate development plan, and urban zoning plan. ${ }^{106}$ Real estate development on a granted land use right also must correspond with the purpose stated in the granting contract. ${ }^{107}$

A purchaser, lessee, lender, or other investor risks violating one of the preceding laws or regulations and faces a variety of consequences depending on the law or regulation violated. For example, failure to develop land on a granted land use right in accord with the granting contract can result in forfeiture of the land use right to the State. ${ }^{108}$ The consequence of violating one or more of the various land use plans is not certain.

Buildings also must comply with standards established by various government agencies, including the Ministry of Construction, other Ministries subordinate to the State Council, and the Construction Administration of each province, autonomous region, or municipality that is directly subject to the Central Government. ${ }^{109}$ Following a given building's construction, government inspectors may instruct the developer to make changes if they are not satisfied with the quality or other conditions of the building. ${ }^{110}$ Neither a building nor the infrastructure of a project may be used until it has been issued a certificate verifying that it has passed inspection. ${ }^{111}$

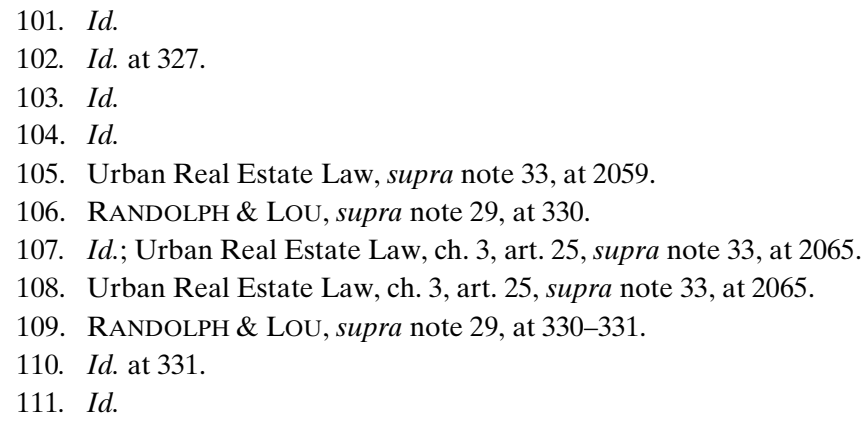


The level of detail in the land use plans is such that actual parcels of land encompassed within the plan are not described. ${ }^{112}$ Comprehensive plans can be changed, but any changes must be approved through all the same processes of review established for original plans. ${ }^{113}$ In areas that have not yet been zoned, local regulations may provide for issuance of an interim use permit, but upon the government's demand such interim uses must be discontinued and no compensation will be made for investments lost as a result. ${ }^{114}$ Additionally, as part of this system, a special tract development process is available for foreign funded developers. ${ }^{115}$ To date, the special tract development process is confined to development plans to be located in Special Economic Zones, Coastal Open Cities, or Coastal Economic Areas. ${ }^{116}$

Certainly, an expert on Chinese land use and zoning laws is needed to guide any purchaser, lender, or investor through the maze of laws, plans, and regulations that apply to any particular parcel. The risk to the investor is, of course, the inability to realize investment-backed expectations because land use plans or zoning laws apply differently than the investor anticipated.

2. Restrictions on Transfer of Land Use Rights by Agricultural Collectives. Since 1982, all land in China has been owned either by the State or by agricultural collectives. ${ }^{17}$ The State owns land in the cities, while agricultural collectives own land in rural and suburban areas (including house sites, privately farmed plots of cropland, and "hilly land"), except for portions that belong to the State under other provisions of the law. ${ }^{118}$ Detailed regulations deal with the circumstance of urban areas expanding onto agricultural collective land. ${ }^{119}$ The State also can requisition land from agricultural collectives when the State determines that it needs the land for public non-agricultural

112. Id. at 139 .

113. Id. at 137.

114. Id. at 140 .

115. Id. at 142; Provisional Regulations Governing Foreign Investment in Development and Operation of Tracts of Land (State Council May 19, 1990), translated in WAN ET AL., supra note 29 , at 2109.

116. RANDOLPH \& LOU, supra note 29 , at 142.

117. XIANFA [CONSTITUTION], art. 10 (amended 1988) (P.R.C.), translated in WAN ET AL., supra note 29; see also RANDOLPH \& LOU, supra note 29, at 59.

118. XIANFA [CONSTITUTION], art. 10, (amended 1988) (P.R.C.), translated in WAN ET AL., supra note 29.

119. For further discussion of the expansion into agricultural collectives, see RANDOLPH \& LOU, supra note 29, at 62-64. 
purposes; when requisition occurs, the agricultural collective is merely permitted to apply for compensation and settlement fees. ${ }^{120}$ Agricultural land that has been put to use for various vital public projects also belongs to the State, regardless of whether the land would otherwise have belonged to an agricultural collective. ${ }^{121}$

Currently, it is not possible to lease, mortgage, or transfer ownership of agricultural collective land. ${ }^{122}$ Agricultural collectives have the power to create land use rights only in members of the collective for residential and agricultural purposes. ${ }^{123}$ Thus, without approval from the county government, agricultural collectives cannot contribute land use rights to joint enterprises or joint ventures as investments. ${ }^{124}$ Furthermore, agricultural collective land cannot be leased, though buildings may be. ${ }^{125}$ This is inconsistent with the 1988 amendments to China's 1982 Constitution, which recognize the right to transfer granted land use rights. ${ }^{126}$ However, the Constitution does not clearly state whether the State has the sole power to transfer land use rights, nor does it expressly prohibit transferability of land use rights on agricultural collective land. ${ }^{127}$ The Land Administration Law (as amended in 1988) did provide clearly that land use rights on both State land and agricultural collective land are transferable, but the 1998 Land Administration Law expressly prohibits such a practice. ${ }^{128}$ The State Council has not adopted implementing rules for granting and transferring land use rights of agricultural collective land. ${ }^{129}$

Illegal transactions of agricultural land occur frequently in some areas. ${ }^{130}$ A 1998 Circular on Strengthening Management of Transfer of Land Use Rights and Strictly Banning Speculative Land Dealing, issued by the General Office of the State Council, instructed local governments to strengthen control over urban and rural land used for non-agricultural projects and to halt illegal occupancy of land by nonagricultural projects. ${ }^{131}$ Additionally, in 1999, the State Land Admini-

\footnotetext{
120. Id. at 73-74.

121. Id. at 65 .

122. Id. at 82 .

123. Id.

124. Id. at 81 .

125. Id. at $67,199-200$.

126. Id. at 82 .

127. $I d$.

128. Id.

129. Id.

130. Id. at 28 .

131. Id.
} 
stration issued a Circular on Strengthening the Management of "Orchard, Manor and Other Agricultural and Forestry Development Activities," instructing that "other agricultural and forestry development" must comply with the comprehensive land use plan and be approved via the official application and approval process. ${ }^{132}$

Thus, a purchaser of or investor in land use rights on land that borders an urban area must determine whether the land is owned by the State or by an Agricultural Collective. If the land is owned by an Agricultural Collective, the investor or purchaser must confirm that the Agricultural Collective obtained approval from the county government to contribute land use rights to joint enterprises or joint ventures as investments.

3. Uncertain Rights of Foreign-Investment Enterprises. Laws regarding land use rights for Chinese-foreign investment joint ventures are fairly definite, as are those for Chinese-foreign contractual joint ventures. ${ }^{133}$ The law as to ownership of land use rights by wholly foreign-investment enterprises, however, is unclear. ${ }^{134}$ According to one set of rules, local governments at or above county level must make arrangements with respect to the land to be used by any wholly foreign-investment enterprise. ${ }^{135}$ These rules require a foreign-capital enterprise to go through the procedure for obtaining the land use right and the land use right certificate within thirty days of obtaining its business license. ${ }^{136}$ The foreign enterprise must present its business license to the land administration bureau at or above the county level in the place where the enterprise is to be located. ${ }^{137}$ While the rules do not require a contract between the wholly foreign-investment enterprise and the land administration bureau, ${ }^{138}$ most wholly foreigninvestment enterprises do enter into contracts with the local land administration when they obtain land use rights. ${ }^{139}$ The absence of such a contract, however, should not detract from the enterprise's land use right. $^{140}$

4. Risks Involving Leases. Article 28 of the Land Registration Rules refers to "State-owned land which has been lawfully leased from the government land administration bureau." 141 Yet no basis for leasing government land appears in the various laws governing land use rights in China. ${ }^{142}$ As explained above, land in China is owned either by the State or agricultural collectives, which can alienate longterm rights to use such land. ${ }^{143}$ Only after such a land use right has

132. $I d$. 
been granted by the land administration bureau to a grantee is there a provision for the grantee to lease the land use right. ${ }^{14}$

In addition to the requirements for registration of leases of land use rights, regulations require that the leases of buildings be registered separately with the Building Administration at the city or county level within thirty days of execution or revision. ${ }^{145}$ Upon registering the building lease, the lessee receives an occupancy certificate that establishes the lessee's legal right to occupy. ${ }^{146}$ Registration of the land use right is a condition of its validity, ${ }^{147}$ but the regulation requiring registration of building leases is vague as to the impact of failure to register. ${ }^{148}$ Is an unregistered building lease invalid? If a lease of land use rights and building is registered with the Land Administration Bureau, but not with the Building Administration, would it be defeated by a party who subsequently acquires an interest in the building? ${ }^{149}$

Professors Randolph and Lou, in their book Chinese Real Estate Law, write that if, after thirty days, a lease is not registered and a subsequent party, without knowledge of the preexisting lease, enters into a lease for the same property and registers it, the new registration would validate the second lease as against the first tenant. ${ }^{150}$ They posit, however, that if the first tenant has taken possession, not only does that give notice to the second lessee, but possession also raises

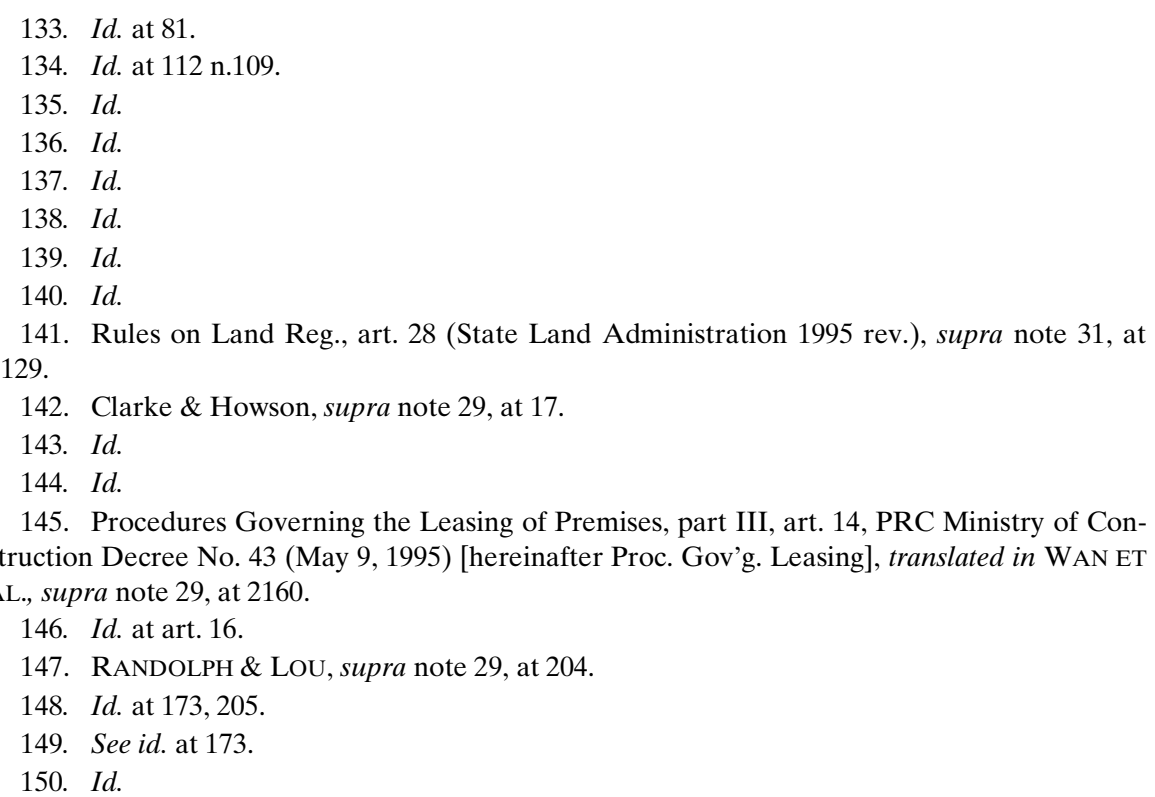


the first tenant's rights closer to in rem status. ${ }^{151}$ A person holding an in rem right has priority over someone with a mere "credit right." Nevertheless, since leases in China are not explicitly in rem rights, the authors cannot say definitively that a tenant in possession under an unregistered prior lease would have priority over a bona fide tenant under a second lease. Rather, they can conclude only that where tenants have begun to occupy leased property, their right to the leased property is more likely to be protected than rights under a lease without occupancy. ${ }^{153}$

China's 1999 Contract Law states that a lease shall have a term of no longer than twenty years and that any provision for a longer term is invalid, though the lease will remain valid for the twenty-year maximum. ${ }^{154}$ Local governments with jurisdiction over agricultural collective property in urban areas can regulate the use of that property and can further restrict the lease term. ${ }^{155}$ If the parties enter into a lease term that is longer than the term of the land use right, the consequence is uncertain, though it may simply be viewed as an agreement that the landlord will seek renewal of the land use right when it expires. ${ }^{156}$

China's Civil Law recognizes a right of first refusal in a tenant as to both sale and reletting of leased commercial and residential property. ${ }^{157}$ It is not certain whether the first tenant would have a claim to a right to release if a new tenant has a better credit standing, but the first tenant would have a superior claim so long as the first tenant can reasonably perform the lease's new terms, even if the tenant is not as financially strong as a new tenant. ${ }^{158}$

Chinese law does not presume that a tenant may assign or sublet the lease. ${ }^{159}$ The lease must expressly permit the tenant to sublease or

\footnotetext{
151. Id.

152. Id.

153. Id. at $173,205$.

154. Id. at 207.

155. Id.

156. Id.

157. The tenant has the right, within three months of receiving notice, to match the terms of any other offer to lease the property for another term. Id. at 214. Also, if a residential tenant dies during the lease term, family members residing with the tenant for more than two years are entitled to continue to live in the property for the remainder of the lease term. Proc. Gov'g. Leasing, part II, art. 11, supra note 145, at 2159.

158. RANDOLPH \& LOU, supra note 29, at 214.

159. Id. at 212; see also Proc. Gov'g. Leasing, part I, art. 3, part V, art. 27, supra note 145, at
} 2163. 
assign. ${ }^{160}$ Theoretically, leasehold estates cannot be mortgaged in China because they are credit rights, not rights in rem. ${ }^{161}$ It may be that the transfer of an interest to a leasehold mortgagee would be treated as a transfer of the lease, however, and a sale of the landlord's interest in a lease would not terminate the lease. ${ }^{162}$

It is uncertain whether a mortgage on a land use right has priority over subsequent leases by the mortgagor. ${ }^{163}$ Thus, it is also unclear if foreclosure of a mortgage during the term of a lease extinguishes the lease, whether it arose either prior or subsequent to the mortgage. ${ }^{164}$

5. Renewal Rights. Holders of granted land use rights may apply for renewal at least one year prior to the expiration of the term, ${ }^{165}$ though local regulations are permitted to alter that requirement. ${ }^{166}$ The current law provides that the Chinese government must approve the renewal application unless it needs to recover the land in the public interest. ${ }^{167}$ It is uncertain at this time how much protection this renewal right gives to purchasers and investors since none of the granted land use rights given after the 1988 Constitutional amendment (typically for terms between 30 and 70 years) are near expiration. ${ }^{168}$

If the renewal is approved, the holder must re-register with the land administration and pay a new fee for the grant of the land use right according to the value of that right (exclusive of the building, which has separate ownership) at the time of the renewal. ${ }^{169}$

6. Co-Owners' Rights. Chinese law recognizes co-ownership. ${ }^{170}$ Partnership, marriage, ownership of apartment units in multi-tenant buildings, ${ }^{171}$ and other special relationships give rise to co-

160. Proc. Gov'g. Leasing, part I, art. 3, part V, art. 27, PRC Ministry of Construction Decree No. 43 (May 9, 1995), supra note 145, at 2163.

161. RANDOLPH \& LOU, supra note 29, at 218, 244.

162. Id. at 219.

163. Id.

164. Id.

165. Urban Real Estate Law, ch. 2, art. 21, supra note 33, at 2063.

166. RANDOLPH \& LOU, supra note 29, at 128.

167. Urban Real Estate Law, ch. 2, art. 21, supra note 33, at 2063.

168. See RANDOLPH \& LOU, supra note 29, at 128.

169. Id. at 129; see also Urban Real Estate Law, ch. 2, art. 21, supra note 33, at 2063.

170. RANDOLPH \& LOU, supra note 29, at 45.

171. "Modern private ownership of apartment units in multi-tenant buildings includes, as a matter of law, co-ownership of the building structure and the land use right supporting the 
ownership. ${ }^{172}$ If the co-ownership is "by shares," the co-owners may sell their interests independently, but other co-owners may have a preemptive purchase right. ${ }^{173}$ If the co-ownership is "common ownership," the type of ownership relation resulting from marriage, the coowners collectively have all of the rights and are subject to all of the burdens of ownership. Co-owners have no individually transferable rights. ${ }^{174}$ Since individual interests cannot be sold, other common owners need no preemptive rights. ${ }^{175}$

7. Neighborhood Rights. Another type of shared interest is the "neighborhood right."176 "Neighborhood rights" are roughly equivalent to American common law easements by necessity. ${ }^{177}$ When one party needs to cross over or through the property of another for access to the first party's property, for water, drainage, ventilation, utility services, or lighting, Chinese law recognizes and protects the right to use land in this manner as a neighborhood right. ${ }^{178}$ Thus, neighborhood rights are both an extension of and a limitation on property rights. ${ }^{179}$ If use rights conflict, the conflict is resolved by the rule of "first in time, first in right." 180 Because neighborhood rights arise as a matter of law, rather than by conveyance, they cannot be found in the land registry.

The existence of lessees' rights of first refusal raises the question of whether a shared use right in a building is an in rem right owned by the user or whether it is simply a neighborhood right, or easement. ${ }^{181}$ If the interest is an in rem right, the user accordingly would have a preemptive right to purchase the building subject to the use right,

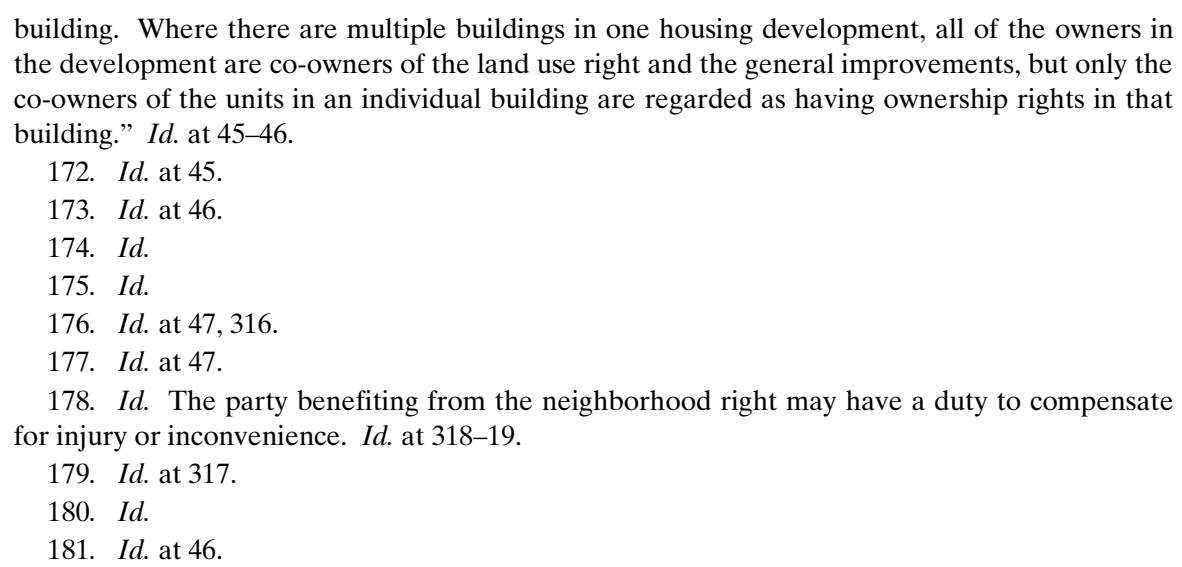


should that building be sold. ${ }^{182}$ If the interest is more in the nature of a neighborhood right, then no preemptive right exists. ${ }^{183}$

In private housing complexes that are developed in a manner similar to American condominiums, several questions arise as to the nature of the ownership rights of the occupants of a building. ${ }^{184}$ Clearly, unit occupants own the space within their own units and have at least neighborhood rights that may be upheld against the rest of the building. ${ }^{185}$ Do they, however, have ownership interests in the common areas? ? $^{186}$ If so, do occupants have co-ownership by shares, so that each has a percentage interest in the common area property and a preemptive right to acquire the interests of others who decide to sell $?^{187}$ If preemptive rights exist, they should be waivable. Will such a waiver be enforceable? Must the waiver be registered? ${ }^{188}$

Finally, in the General Principles of Civil Law, China recognizes the basic concept of nuisance: one cannot use one's property in a way that unreasonably interferes with the use and enjoyment of neighboring property. ${ }^{189}$ This obligation covers noise, drainage of wastewater and other waste, and creation of hazards on one's own land that may endanger neighboring property. ${ }^{190}$ The concept of nuisance may extend to the blocking of air and light from neighboring properties, though there is no specific provision of Chinese law on air and light rights. ${ }^{191}$

8. Easements. Chinese law does not expressly recognize or reject the concept of private grants of easements, ${ }^{192}$ and China's land registration law lacks provisions for registering easements. ${ }^{193}$ A contract for the transfer of a land use right could contain promises in the nature of easements; this contract would become part of the registration file for the land use right, but such promises likely would not ap-

\footnotetext{
182. Id. at 46 .

183. Id.

184. Id. at 47.

185. $I d$.

186. $I d$.

187. Id. at 47-48.

188. Id. at 48.

189. Id. at 319 .

190. Id.

191. Id. at 320 .

192. Id. at 322 .

193. Id. at 323 .
} 
pear on the registration certificate or card. ${ }^{194}$ A risk for both investors in the burdened land and in the benefited land is the uncertainty as to whether such a right would bind successive owners of the burdened land. ${ }^{195}$

9. Covenants. Chinese law currently does not expressly recognize or permit registration of covenants that create a duty of use or a restriction on the use of a parcel of real property. ${ }^{196}$ If covenants in transfer documents relating to the use of land, or the maintenance or operation of common areas, are treated merely as credit rights, they will not be binding on successors to the burdened land use right unless those successors contract to assume the covenants when they acquire the land use right. ${ }^{197}$ Thus, developers face the risk that transferees of individual housing or office units will not be bound by covenants relating to use, maintenance, or fee obligations of the property unless the developer contracts individually with each transferee to assume the covenants of their transferors. ${ }^{198}$ Conversely, purchasers, lessees, lenders, and investors are at risk of government enforcement of restrictive covenants imposed in original governing documents, even though they do not appear in the land registry records, if they are deemed necessary for the operation of a housing, office, or shopping development. ${ }^{199}$

10. Inheritance Laws and Spousal Rights. Ownership interests in buildings may be inherited. ${ }^{200}$ A landlord's rights in leases of buildings are inheritable. ${ }^{201}$ Land use rights, whether granted or allocated, also can be inherited. ${ }^{202}$ Most individual Chinese citizens own land use rights only for residential or agricultural purposes. An heir or devisee of a residential property cannot transfer it for commercial purposes without authorization from the State and, in the case of an allocated land use right, the assessment of a fee for converting the

194. Id.

195. Id.

196. Id. at 323-24.

197. Id. at 324 .

198. Id.

199. Id. at 325 .

200. Id. at 50 .

201. $I d$.

202. Prov. Reg. Land Grant and Assignment, supra note 30, at 2106 ("Land use rights acquired by individuals according to the provisions of these regulations may be inherited."). 
allocated land use right to a transferable granted land use right. ${ }^{203}$ Homestead housing rights are inheritable, but agricultural rights assigned by an agricultural collective are not. ${ }^{204}$ Many additional restrictions exist as to whether types of land use rights may or may not be inherited. Regulations also give rights to a deceased tenant's family members for a certain period of continued occupation. ${ }^{205}$

In 1995, the Ministry of Construction issued Regulations Governing Urban Real Estate Transfers that appear to address all forms of transfer, including sales, gifts, contributions to business enterprises, and ownership changes resulting from the merger, take-over, or purchase of enterprises. ${ }^{206}$ However, the Regulations do not specifically mention transfer by inheritance, ${ }^{207}$ leaving unanswered questions concerning the application of their restrictions when land use rights are inherited.

Chinese marriage law provides rights in both spouses to all property acquired by either spouse during the marriage. ${ }^{208}$ Real property owned by one spouse prior to the marriage can remain separate property unless it is used or managed jointly by both spouses for eight years following marriage, at which time it becomes a joint asset. ${ }^{209}$

11. Tax Liability. Taxes are assessed in China on real property's development, use, and value, as well as on the income resulting from its transfer and productivity. ${ }^{210}$ Among the particular taxes to which land use rights could be subject are: Land Use Charge; Cultivated Land Occupation Charge; Building Property Tax; Contract Tax; Inheritance Tax; Stamp Tax; Fixed-Asset Investment Adjustment Tax; Business Tax; Value-Added Tax on Land; Enterprise Income Tax; Income Tax on Foreign-Investment Enterprises and Foreign Enterprises; and/or Individual Income Tax. ${ }^{211}$

A purchaser or lender certainly would need to learn how to determine whether all taxes that apply to a particular parcel and transaction have been paid. The consequences of a failure to pay any of the above taxes may depend on the particular tax. For example, the

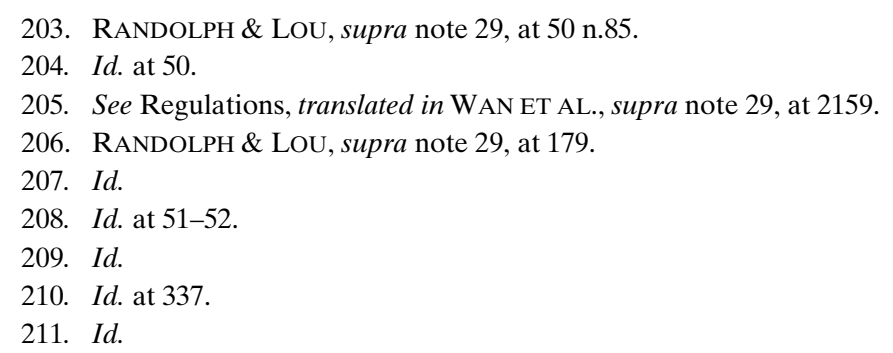


failure to pay may result in additional taxes or a monetary penalty. ${ }^{212}$ Of greatest concern is whether the law permits the land to be confiscated or sold for unpaid taxes.

\section{Risks in Transferring Land Use Rights}

Risks to investors arise from ambiguities or vagueness in the laws and regulations governing the transfer of land use rights. For example, the 1994 Law Governing Urban Real Estate provides that, if land is to be used for commercial, tourist, or recreational purposes, or for luxury housing, then the grant of the land use right must be by auction or bid invitation "if possible." ${ }^{213}$ A grantee and grantor who conclude that an auction or bid invitation is "not possible" and proceed with a transfer, risk a subsequent government determination that the auction or bid invitation process should have been employed. Furthermore, no national rules exist for the auction procedures, though many provincial or local governments have established their own formal procedures. ${ }^{214}$ Whether the grant of land use rights would be void or voidable if it were made without auction or bid invitation, or if it did not comply with all auction requirements is uncertain. Similar risks are discussed in subsections 1-14 below.

1. Transferability of Granted Land Use Rights. Grantees of granted land use rights cannot transfer those rights until they have met preconditions designed to assure that the purpose of the original grant is accomplished and that the grantee was not merely a speculator. ${ }^{215}$ Preconditions to the transfer of a granted land use right include the following:

212. See, e.g., id. at 359 .

213. Procedures for the Administration of the Leasing Premises in Urban Areas, Decree No. 43, P.R.C. Ministry of Construction, Part III (May 9, 1995) [hereinafter Proc. Urban Area Leasing], translated in WAN ET AL., supra note 29, at 2062. The translation of this law by Wan states that the auction or bid invitation must be used "when suitable conditions are present." WAN ET AL., supra note 29, at 2062; see also RANDOLPH \& LOU, supra note 29, at 147, stating:

If no specific limit on the land user's qualifications exists or the land's permitted use is not described in detail, the granting of the land use rights must be carried out by auction. If public considerations on the granting of the land use right must be made or the use of the land is strictly limited, then the granting of the land use rights is to be made by public bid invitation. Private negotiation is only to be used in the granting of land use rights in the process of state-owned enterprises reform and the granting of land use rights for public purposes. Even where private negotiation is permitted, the price for a granted land use right cannot be less than the minimum price established by the county or city government. Provincial or local rules may require the auction process to be used in even more situations.

214. RANDOLPH \& LOU, supra note 29 , at 148.

215. Id. at 183 . 
(1) The grantee must have paid the land use right fee and obtained the land use right certificate.

(2) The grantee must have commenced the development of the land in accordance with the granting contract. In building projects, this means that the grantee must have invested at least twenty-five percent of the whole projected investment.

(3) If the building construction has been finished, the grantee must have obtained the building ownership certificate. For the sale of housing to foreigners, a permit must have been obtained from the government. ${ }^{216}$

A buyer or lender may believe that these preconditions have been met as a matter of fact and accept a transfer of an interest in a granted land use right only to face the State's contention that the preconditions were not satisfied and the transfer was unlawful.

A common way for a developer to obtain funds for construction is to "presell" or "prelease" the property. ${ }^{217}$ A developer of a housing project is permitted to presell the housing before completion of construction if the first two pre-conditions above have been satisfied and if the developer obtains both a zoning license for the project and a presale permit from the Building Administration at or above the county level. ${ }^{218}$ If the housing is to be pre-sold to foreigners, a special permit must be obtained. ${ }^{219}$

Housing purchased from work units and housing purchased at subsidized prices can be sold if the owners have registered their interests and acquired title certificates. ${ }^{220}$ A purchaser of or investor in housing units will want the seller to provide approval from the local housing administration, the seller's title certificates, personal identification, and written consent of the adults who live in the housing. ${ }^{221}$ If the housing is co-owned by a work unit, the seller should provide a written statement from the work unit waiving its right of first refusal to buy the housing. ${ }^{222}$ Purchasers and lenders bear the risk of ascertaining whether a transferor's right to housing is co-owned by a work

216. Proc. Urban Area Leasing, Part III, supra note 29, at 2068. For subdivisions, the developer must have installed the infrastructure. RANDOLPH \& LOU, supra note 29, at 183.

217. RANDOLPH \& LOU, supra note 29 , at 184.

218. Proc. Urban Area Leasing, Part III, supra note 29, at 2069.

219. RANDOLPH \& LOU, supra note 29, at 184.

220. Id. Owners may not "trade" such housing in many circumstances. The facts of a trade would have to be closely examined before a title to residential property obtained via a trade could be secure. Id. at 184-185.

221. Id. at 185.

222. Id. 
unit, was purchased from a work unit, or was purchased at a subsidized price

2. Risks in Process of Converting Allocated Land Use Right To Granted Land Use Right. Because granted land use rights are transferable and allocated land use rights are not, ${ }^{223}$ a procedure exists by which to convert an allocated land use right into a transferable granted land use right. ${ }^{224}$ The process requires several steps. Certain procedures have been described as devoid of clear implementing provisions. ${ }^{225}$ If the required steps for the conversion to a transferable land use right were not all properly followed, it is unclear whether the transfer would be void, voidable, or enforceable by the purchaser or mortgagee.

Another ambiguity is that Article 36 of the 1995 revised Land Registration Rules suggests that a Chinese party to a foreign-invested enterprise may make its equity contribution in the form of land use rights to collective-owned land. ${ }^{226}$ Yet other regulations suggest that before agricultural collectives may contribute their land as equity, they must first convert it to "state-owned land" and be granted land use rights. $^{227}$

Other situations also may exist in which it is uncertain whether a particular allocated land use right should have been taken through the process of conversion to a granted land use right before it was legally transferable to a purchaser or investor. China's 1995 Transfer Regulations indicate some circumstances in which it is not necessary to convert an allocated land use right before transfer. ${ }^{228}$ However, two or three of the circumstances are stated generally enough that the government appears to have great discretion in determining whether these exceptional circumstances exist or not. ${ }^{229}$ An investor faces a risk in assuming that the intended use of the land is exempt from prior conversion to a granted land use right, only to learn subse-

223. See supra section II.

224. RANDOLPH \& LOU, supra note 29, at 143.

225. Id. at 146.

226. Proc. Urban Area Leasing, Part III, supra note 29, at 2130.

227. Clarke \& Howson, supra note 29, at 17; see supra section II.B.

228. RANDOLPH \& LOU, supra note 29 , at $180-82$. These circumstances primarily include when the property is used for public purposes and transfer of homestead property for continued residential use.

229. For example, the conversion of an allocated land use right into a granted land use right is not required when the government at county level or higher "considers that it is impossible or unnecessary to permit the conversion." Id. at 182. 
quently that the government disagrees with that interpretation. The consequence of the investor's misinterpretation is not established by law; two consequences are conceivable: the error may result only in the government's assessment of the fee the investor would have had to pay to convert the land use right; or, the transfer to the investor may be held invalid.

3. State's Right to Terminate Land Use Rights. Another investor risk is that the State may recover both granted and allocated land use rights for a public purpose, paying the holder "appropriate compensation" for the loss of the land use right. ${ }^{230}$ The publicity generated when such "reclamations" occur make this one of the most feared risks, as illustrated by the recent example involving the Beijing district government's reclaiming the rights to a man's 350-year-old house in order to sell the land to a bank for a 10-story bank building. ${ }^{231}$ The city compensated the owner of the land use rights, but, according to newspaper reports, the compensation represented only one-tenth of what the government stood to receive from the bank being built on the site. ${ }^{232}$

4. Flaws in Process of Setting Land Use Fee. A purchaser must pay the entire land use fee prior to registering the land use right. ${ }^{233}$ Before payment of the fee, the grantee has only a credit right, not a right in rem. ${ }^{234}$

In 1994, the State Planning Commission established a set of basic principles for establishing the value of land use rights. ${ }^{235}$ The land values it set are not maximums or minimums and generally do not prevent investors, purchasers, or mortgagees from setting a market price. $^{236}$ However, in some areas, local governments have adopted regulations giving the government a right of first refusal as to properties under contract for a price below that established by the Basic Land Price System. ${ }^{237}$ One presumes that the government could only

230. Proc. Urban Area Leasing, Part III, supra note 29, at 2058. This risk would not be covered by either standard American title insurance policies or the standard international policies that American title insurance underwriters have promulgated. See infra section III.C.

231. See, e.g., supra note 40 , at 4.

232. Id.

233. See Proc. Urban Area Leasing, Part III, supra note 29, at 2099-100.

234. RANDOLPH \& LOU, supra note 29, at 152 .

235. See Proc. Urban Area Leasing, Part III, supra note 29, at 2067; RANDOLPH \& LOU, supra note 29 , at 153 .

236. RANDOLPH \& LOU, supra note 29 , at 154 .

237. Id. at 156. 
exercise this right until the private transaction has been registered. The local government's right of first refusal should not void a registered title, at least so long as the transferor and transferee complied with all requirements for notifying the local government of the contract price before closing the transaction and registering it

5. Forfeiture of Land Use Right if Use is Not Commenced or Continued. Granted land use rights are created by the State for specified purposes. ${ }^{238}$ If the use for which a land use right is granted is not properly commenced within two years, it is forfeitable to the State. ${ }^{239}$ No compensation is payable for either the loss of the land use right or the improvements. ${ }^{240}$ Conversely, so long as the granted land use right was properly commenced, it does not appear to be forfeitable if the use is not continued. ${ }^{241}$ In contrast, allocated land use rights may be forfeited if the use is not continued. ${ }^{242}$

Commencement of land use usually requires substantial construction, in order to satisfy the national objectives of development and economic growth that supported granting the land use right. ${ }^{243}$ Local governmental regulations may provide other definitions of what constitutes commencement. ${ }^{244}$ In the majority of locales where no specific definition exists, a risk to investors is that the government will disagree with their judgment that the use was "properly commenced" or "continued" and will reclaim the land. The law does permit certain excuses for failure to commence use within the twoyear period, including force majeure, government interference with commencement, and other justifiable excuses. ${ }^{245}$ Again, however, the investor and the government may reach different conclusions regarding whether failure to commence in fact was caused by the alleged force majeure or government interference.

238. Id. at 126.

239. See Proc. Urban Area Leasing, Part III, supra note 29, at 2067; RANDOLPH \& LOU, supra note 29 , at 2065.

240. Id. Also, delay of commencement even for one year can result in a fine of up to twenty percent of the fee paid for the land use right, as well as other legal consequences. $I d$.

241. RANDOLPH \& LOU, supra note 29 , at 130.

242. Id.

243. $I d$.

244. Id. For example, in Shenzhen, local regulations provide that "commencement requires that all development and land use permits be obtained, and twenty-five percent of the planned investment has been expended on the project." Id.

245. Proc. Urban Area Leasing, Part III, supra note 29, at 2065. 
Recent amendments to the law have created uncertainty regarding whether an allocated land use right automatically terminates if the land use is discontinued. ${ }^{246}$ This ambiguity must be clarified before investors may change the use of an allocated land use right without serious risk.

Because of the requirement that project development be commenced as a precondition to sale of a land use right, most land use rights that are transferred have buildings on them. ${ }^{247}$ Buyers and investors need to realize that the building is separate from the land use right and that separate transfers must be made of the land and the building. ${ }^{248}$

6. Transfers of Allocated Land Use Rights from Educational Institutions, Scientific Research Institutes, Cultural Organizations, Health Institutions, and Political Subdivisions. Educational institutions, scientific research institutes, cultural organizations, health institutions, and political subdivisions legally are able to use land allocated to them only for their designated purposes. ${ }^{249}$ In reality, however, these organizations or institutions quite commonly devote their property to revenue-producing purposes. ${ }^{250}$ Local officials have condoned these practices even though the land was allocated for different purposes. ${ }^{251}$ Technically, such activities are inconsistent with the allocated land use right and should occur only after such rights have been converted to granted land use rights. ${ }^{252}$ The practice is so widespread, however, that it is expected that government officials will find a way to fit the development within the list of permitted real estate activities. ${ }^{253}$ Nonetheless, a purchaser or investor cannot be secure that development for purposes other than those for which the land was allocated will be permitted.

Political subdivisions may lawfully hold either granted land use rights or allocated land use rights, but the sole present purpose for their holding land use rights is to carry out their defined institutional purposes. ${ }^{254}$ In the past, they have engaged in real estate development

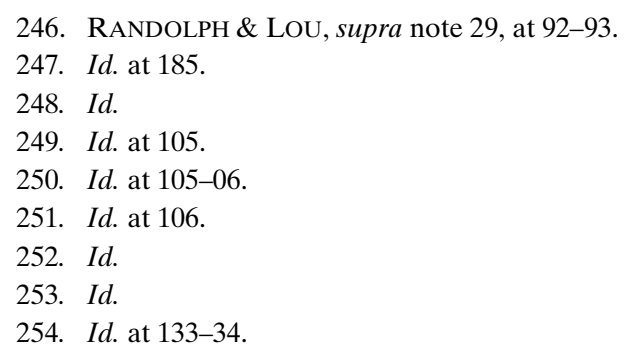


for profit, but this is prohibited, at least in theory. ${ }^{255}$ Therefore, a buyer or investor should be wary of accepting transfers of land use rights from political subdivisions.

7. Restrictions on Standard Form Contracts. A World Banksponsored paper recommends development and use of standard form real estate contracts in emerging markets to save all parties both time and expense in real estate transactions. ${ }^{256}$ However, provisions in China's contract law create the risk that such a contract could be considered null and void. Article 39 of the Contract Law states that "the party that supplies the standard terms shall define the rights and obligations between the parties abiding by the principle of fairness, request the other party to note the exclusions or restriction of its liabilities in reasonable ways, and explain the standard terms according to the requirement of the other party." ${ }^{257}$ Section 40 states that where the party imposing the terms exempts itself from its liabilities, weighs the liabilities of the other party, or excludes the rights of the other party, such terms shall be null and void. ${ }^{258}$ Section 52 further provides that standard terms are invalid when they violate "compulsory provisions of the laws and administrative regulations.",259

An investor needs assurance that a transfer or mortgage of a land use right would not be entirely void if one or more of the clauses of its standard form purchase agreement or mortgage were deemed to violate Chinese contract law. One way to avoid this risk is to use the standard forms that the Chinese government has promulgated for transfers of land use rights and transfers of buildings. ${ }^{260}$ A contract form for the transfer of land use right has been created by the Ministry of Construction, ${ }^{261}$ and the Urban Building Administration has created a contract form for the transfer of buildings. ${ }^{262}$ Neither form is mandatory, and the parties may add to or vary their terms. ${ }^{263}$ Using the basic structure and terms of these contracts, however, may reduce

255. Id. at 133 .

256. Schwarzwalder, supra note 16, at 171.

257. RANDOLPH \& LOU, supra note 29 , at 41.

258. Id.

259. $I d$.

260. Id. at 185 .

261. Id. A copy of Grant Contract for State-Owned Land Use Rights is reproduced as Appendix I, and a copy of Supplementary Grant Contract for Allocated Land Use Rights is reproduced as Appendix II in WAN ET AL., supra note 29, at 2001, 2011.

262. RANDOLPH \& LOU, supra note 29 , at 185.

263. Id. 
the risk ${ }^{264}$ of a transfer being overturned on the basis that the transfer contract was weighted too heavily in favor of one party.

8. Notarization. While no national notarization requirement exists, certain cities, such as Shanghai, require notarization of transfer, mortgage, leasing, building, and development contracts involving commercial real estate, as well as of contracts involving housing for foreign use. ${ }^{265}$ In Shanghai, contracts for leasing or transfer by auction of properties owned by State enterprises also must be notarized. ${ }^{266}$ Presumably, the land use right or transfer thereof will not be registered without notarization.

Investors risk uncertain consequences if the notarization subsequently is determined to be defective. In many U.S. states, if the notary's commission was expired or the notarization was faulty, the notarized instrument may not be entitled to be recorded, may not give constructive notice, or may not be sufficient as a link in the chain of title. $^{267}$ In China, presumably registration would make the transfer of the title conclusive, regardless of a defective notarization. Certainly, an investor would feel more secure if the law expressly provided for this result.

9. Risks Involving Mortgages and Foreclosure. Laws regulating mortgages exist at several different levels of government in China. Explaining the theory and intricacy of China's law of mortgages is beyond the scope of this Article, ${ }^{268}$ but a lender or investor must be aware of each of them. ${ }^{269}$ The following are some of the risks for lenders and other investors that should be resolved either by legislation or by improvements in China's land title registration system or covered by private title insurance.

264. Id.

265. Id. at $187-88$.

266. Id. at 188 .

267. See Metro. Nat'l Bank v. U.S., 901 F.2d 1297 (5th Cir. 1990); Leeds Bldg. Prods. Inc. v. Sears Mortgage Corp., 477 S.E.2d 565 (Ga. 1996); Messersmith v. Smith, 60 N.W.2d 276 (N.D. 1953); Jesse Dukeminier \& JAMEs E. KRIER, Property 684 (4th ed. 1988); RuFFord G. Patton \& Carrol G. Patton, Patton On Land Titles $§ 354$ (2d ed., Supp. 1998-2000) (1957).

268. See generally RANDOLPH \& LOU, supra note 29 (Chapter 8, "Mortgage Law," explains Chinese mortgage law, drawing distinctions from American mortgage law.); PEI, supra note 29; Andrew John Godwin, The Theory Underpinning the Development of Mortgage Law in China, (2000) (unpublished Master of Laws thesis, University of Melbourne) (on file with the University of Melbourne Library and with the Duke Journal of Comparative and International Law).

269. American standard title insurance policies exclude loss of title as a consequence of the application of laws and government regulations. PALOMAR, supra note 21, § 6.0. 
First, because Chinese law views the building as a separate legal interest, a mortgagee needs to obtain separate mortgages on the granted land use right and on the buildings on such land. ${ }^{270}$ A question exists as to whether allocated land use rights on unimproved land may be mortgaged. ${ }^{271}$ Allocated land use rights likely may be mortgaged only when the land is improved with a building. ${ }^{272}$ Even then, because allocated land use rights are non-transferable, in order to foreclose the mortgage the mortgagee must pay a fee to convert the allocated land use right to a granted land use right at the time of foreclosure. $^{273}$ Because conversion of an allocated land use right to a granted land use right is at the discretion of the State, a risk exists that the State will not approve the conversion for the purpose of permitting the mortgagee to foreclose on the land use right. ${ }^{27}$

If a mortgage loan on an allocated land use right is made to a State-owned industrial enterprise, the mortgage will not take priority over the State's rights and obligations. ${ }^{275}$ The proceeds from the sale of such mortgaged property would go, first, to satisfy the social welfare obligations of that enterprise, and, second, to the State to compensate for the conversion from allocated land use right to granted land use right, and only then to the mortgagee. ${ }^{276}$

As in the United States, if an enterprise or joint venture is to mortgage land use rights, either internal governing documents must give the right to mortgage its land use rights or its board of directors must adopt a resolution to permit it. ${ }^{277}$ Similarly, a joint stock company or limited liability company set up under China's Company Law must obtain the consent of its board of directors, shareholders or members, unless governing documents expressly give the authority to mortgage the company's land use rights and buildings. ${ }^{278}$ If an entity's internal governing documents place a limit on its business life, then

270. RANDOLPH \& LOU, supra note 29, at 240.

271. Id.; see generally Prov. Reg. Gov'g Land Use Rights, supra note 29, at 2141 (The regulation does not mention regulation of land use rights for unimproved land.); see also Prov. Reg. Land Grant and Assignment, ch. VII, arts. 44, 45, supra note 30, at 2105-06.

272. RANDOLPH \& LOU, supra note 29 , at 240-41.

273. Urban Real Estate Law, ch. 4, § 3, art. 50, supra note 33, at 2059. The fee will be based on the value of the land use right at the time of the mortgage. The Bureau of Land Administration must confirm an appraisal of the land before a mortgage can be registered. RANDOLPH \& LOU, supra note 29 , at 241-42.

274. See RANDOLPH \& LOU, supra note 29, at 99.

275. Id. at 241.

276. Id.

277. Id. at 241-42.

278. Id. at 242. 
the term of any mortgages on its real estate cannot exceed the term of the entity's existence.

Land use rights held by a collective-owned enterprise can only be mortgaged with the consent of both the Worker's Congress for that enterprise and the governmental agency given supervisory responsibility over the enterprise. ${ }^{280}$

Uncertainty exists regarding the mortgaging of co-owned property. ${ }^{281}$ An owner in common does not appear able to mortgage that owner's share because the concept does not recognize a separate "share" that can be transferred. ${ }^{282}$ A provision in 1997 Urban Mortgage Measures does indicate that a co-owner of property must obtain the consent of other co-owners to any mortgage. ${ }^{283}$ Nonetheless, this provision does not make clear whether it addresses co-ownership by shares, ownership in common, or both. ${ }^{284}$ It also does not make clear whether it applies only to a mortgage of the entire property or also to mortgaging the co-ownership share. ${ }^{285}$ If a co-owner by shares does mortgage that individual share, the other co-owners by shares would have a preemptive right of purchase in the event of foreclosure, if "other things are equal.", 286 This may mean simply that the co-owners by shares must be permitted to bid at the foreclosure sale. Nevertheless, it limits the mortgagee's ability to work out the debt by having the mortgaging co-owner transfer the land use right to the mortgagee in lieu of foreclosure. ${ }^{287}$

Additional risks exist when mortgagors transfer their land use rights. A mortgagee does not seem to have a right to object to the creation of junior mortgage interests. ${ }^{288}$ However, a mortgagor must notify the mortgagee prior to any transfer of the property right that secures the mortgage. ${ }^{289}$ The transfer is void if the mortgagee does

\footnotetext{
279. Id.

280. Id.

281. Id. at 243.

282. Id. at 244 .

283. Id. at 243 .

284. Id.

285. Id. (citations omitted).

286. Id. at 244.

287. Id.

288. Id. at 258 .

289. Id. See also Godwin, supra note 268, at 96-97 ("Article 48 of the PRC Security Law provides that if a mortgagor mortgages assets that have been leased out, it must provide written notice to the lessee and the original lease contract will continue to have effect.").
} 
not consent to the transfer. ${ }^{290}$ This regulation applies both to sales and leases of property rights. ${ }^{291}$ When a mortgagor wishes to sell the land use right and pay off the existing mortgage, some might interpret the preceding consent requirement to prevent the sale from proceeding unless the mortgagee approves the sale. ${ }^{292}$ Such an interpretation would make sale contracts uncertain until the mortgagee has given approval, even if the sale contract provides that the mortgagee will be paid off at the closing of the sale. ${ }^{293}$ This concern is particularly important because of the practice in China of "preselling" property prior to the completion of a real estate development as a means of obtaining the funding for development. ${ }^{294}$ Until it is certain how Chinese authorities will construe this consent requirement, a presale purchaser bears a risk until the mortgagee consents to the sale that the mortgagor will not be able to deliver good title. ${ }^{295}$

Every mortgage in China should contain provisions permitting the mortgagee to monitor the use of the property to ensure that the conditions of the land use right are being met, since, as discussed in section II.D.5, failure to complete or continue the stipulated land use can result in forfeiture of the land use right. ${ }^{296}$ It is unclear whether Chinese law would permit the mortgagee to avoid the preceding risk by including express covenants in the mortgage contract that make failure to comply with the land use right an event of default that permits the mortgagee to accelerate the debt, take possession and operate the development. ${ }^{297}$ Article 5 of China's 1997 Urban Mortgage Procedures states that a mortgage shall be entered into "in accordance with doctrines of voluntariness, mutual benefit, fairness and good faith." ${ }^{298}$ A mortgage created in accordance with the law "will be protected by the State[;]" "299 conversely, any mortgage that does not

290. RANDOLPH \& LOU, supra note 29, at 258.

291. Id. at 255-56; see also Godwin, supra note 268, at 97 ("Article 49 of the Mortgage Procedures provides that if a mortgagor unilaterally (presumably this means without the consent of the mortgagee) sells, leases, exchanges, gives away or otherwise deals with or disposes of the mortgaged property, such acts shall be invalid and the mortgagor shall be liable to compensate any third party who suffers loss as a result.").

292. RANDOLPH \& LOU, supra note 29, at 258.

293. Id. at 259.

294. Id.

295. $I d$.

296. Id. at 267-68.

297. Id. at 268-69.

298. Id. at 275 .

299. Id. 
meet these standards will not be protected by the State. ${ }^{300}$ Another regulation states that mortgages must not be contrary to the law or the contract for the grant of the land use right. ${ }^{301}$

Mortgages of land use rights, buildings, and certain other property rights must be registered. ${ }^{302}$ The mortgage contract takes effect only upon registration. ${ }^{303}$ If the registry office fails to register the mortgage, the mortgage contract will be valid only between the mortgagor and mortgagee, but the mortgage will not prevail over the interests of good faith purchasers for value. ${ }^{304}$

The extent to which investors can rely on the land register in determining the existence of a mortgage and details of the mortgage, such as term, amount, and a description of the mortgaged property is an issue. ${ }^{305}$ Current Chinese law does not require that the register supply such information ${ }^{306}$ and the registration system is not yet sufficiently staffed or equipped to be reliable in all areas. ${ }^{307}$ If the note secured by the mortgage specifies interest or the interest rate, but those details are not registered with the mortgage, the interest will not be given priority. ${ }^{308}$

Recent Chinese Supreme Court draft provisions seek to make the register more conclusive. They provide that (1) if the land description or rights of the parties described in the mortgage vary from that shown in the registry, the registry's details shall be conclusive; and (2) if registered rights are mistakenly canceled, those rights will be deemed to not exist. ${ }^{309}$ If the application of these provisions results in a subsequent transferee obtaining unencumbered ownership or a mortgage with a higher priority, the "party at fault" would be liable to compensate for the mortgagee's loss. ${ }^{310}$ The "party at fault" may include the registry office. Nevertheless, mortgagees are not assured of compensation when they sustain a loss due to reliance on an errone-

300. Id.

301. Id. at 297-98.

302. Urban Real Estate Law, ch. 5, § 3, art. 61, supra note 33, at 2059; Prov. Reg. Land Grant and Assignment, ch. V, art. 35, supra note 30, at 2097.

303. See Godwin, supra note 268 , at 113.

304. Id. at 119 .

305. Id. at 120 .

306. Id.

307. See id.

308. Id. at 121.

309. Id. at 120-21.

310. Id. at 121. 
ous registry. ${ }^{311}$ For example, in a 1998 case reported by the Shanghai Real Estate Newspaper, a registry official allowed a bank to register a mortgage although the property had previously been the subject of a court's "freezing order." the freezing order prior to registering the bank's mortgage, but had overlooked it at the time that the mortgage was registered. ${ }^{313}$ The court held that, despite its registration, the mortgage was defeated. ${ }^{314}$ This result permitted the creditor who had obtained the freezing order to assign the property free of the mortgage. ${ }^{315}$ The bank sued the registration authority for the loss of its security. ${ }^{316}$ The case is on appeal, but similar cases have held that an attempt to dispose of property that is subject to a freezing order is invalid.

A lender accepting a mortgage of land use rights in China also has the risk of failing accurately to understand or to follow China's security laws and foreclosure process, including procedures for notice, acceleration of debt, possession after default, and collection of rents. Lenders accepting junior mortgages must understand the particular law pertaining to rights of junior mortgagees. ${ }^{318}$ Also, parties purchasing land use rights in foreclosure must know which interests were extinguished by the foreclosure sale and which interests they may be taking subject to. ${ }^{319}$ Other issues involving mortgages may arise in bankruptcy. ${ }^{320}$

10. Dians and Other Creditors' Rights. A dian is an agreement whereby the grantor, in exchange for a cash payment, confers upon the holder the possession of a parcel of property, along with all the benefits ownership of the property confers, for a specific term. ${ }^{321}$ The agreement can provide that if the grantor of the dian does not pay the

311. Id.

312. Id.

313. Id.

314. Id.

315. Id.

316. Id.

317. Id.

318. See generally RANDOLPH \& LOU, supra note 29, at 286-88 (arguing that a reasonably cautious junior mortgagee should perform an inspection of mortgage registration records since registration provides constructive notice of the mortgagee's rights).

319. See, e.g., id. at 281 .

320. See infra section II.D.10; see also Godwin, supra note 268, at 98-100 (explaining that only a registered mortgage contract will prevail over the rights of ordinary creditors in bankruptcy).

321. RANDOLPH \& LOU, supra note 29 , at 303-04. 
debt by the end of the term, ownership will pass to the holder, but if the parties do not expressly provide otherwise, then the grantor retains the right to redeem the property for ten years after the term. ${ }^{322}$ If the parties fail to state a term, then the grantor has thirty years in which to redeem. ${ }^{323}$ The dian is a right in rem which is to be registered in the registry for buildings. ${ }^{324}$ A difficulty, however, is that the dian is primarily employed in rural areas where, today, there is no formal registry for buildings. ${ }^{325}$ If no means exist for registering a dian, it is questionable whether the interest could still be enforceable against a purchaser or mortgagee of the property. ${ }^{326}$ A purchaser or mortgagee can limit the risk of taking subject to a dian by verifying that the seller or mortgagor actually is in possession of the property. ${ }^{327}$

Chinese law permits pre-bankruptcy transfers and special "arrangements" made within six months prior to a debtor's bankruptcy filing to be set aside and the property brought back into the bankruptcy estate. ${ }^{328}$ Such a transfer can be set aside even up to one year after the conclusion of the bankruptcy. ${ }^{329}$ The debtor's existing contracts also can be either affirmed or avoided. ${ }^{330}$ If avoided, the other party to the contract is left with an unsecured creditor's claim. ${ }^{331}$ Purchasers of property from a bankruptcy estate appear to face significant risks because of the amount of discretion that Chinese bankruptcy law gives to government authorities. ${ }^{332}$

11. Mineral \& Air Rights. The State has reserved underground rights and the right to surface and subsurface minerals. ${ }^{333}$ Even where land is owned by an agricultural collective, the State generally owns any natural resources. ${ }^{334}$ Thus, transfers of both granted and allocated land use rights transfer only the surface rights to the land and do not include underground or airspace rights not directly related to the

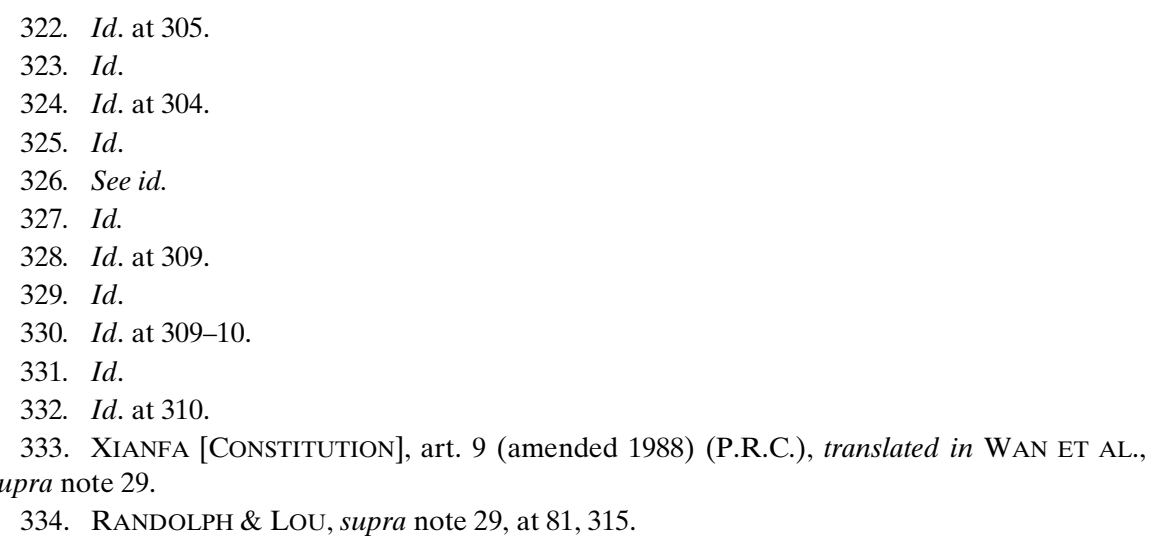


agreed-upon purpose for the right. ${ }^{335}$ The State likely has the power to authorize an intrusion on rights of the owner of the surface land use rights for purposes of extracting resources if it is in the public interest, though the State likely would have to compensate the surface interest holder for damages. ${ }^{336}$

\section{ENHANCED LAND TITLE SECURITY FOR PURCHASERS AND INVESTORS IN CHINA}

As mentioned in section II, some of the risks described above are present simply because existing law is not enforced. Some risks exist because the law is not clear. A few risks exist because the law has made a conscious choice in balancing interests of the public against those of individual owners of land use rights, or in balancing the interests of particularly-situated land use right owners against those of others. Whatever the reason for the risk, investment will be stimulated to the extent that the risk of loss to investors can be recognized and reduced. The means of risk-reduction simply must differ depending on the reason for the risk.

To provide sufficient security to stimulate investment that involves land use or land development, China needs to focus on three components. First, investors want to be able to rely on the rule of law for assurance as to what rights landowners legally hold and may legally transfer to purchasers, lessees, mortgage lenders, and other investors. ${ }^{337}$ Second, investors want a land title record system that is conclusive, accessible, reliable, efficient, and economical. ${ }^{338}$ Third, investors desire measures that reduce risks to their title to land and in-

335. Id. at 126 .

336. Id. at 315 .

337. GATES, supra note 1 , at 224 , stating:

Secure title ... is closely linked to the origins of financial markets. An owner's stake must be clear; otherwise property rights cannot facilitate the transfer of resources to their highest valued use. When secure, property rights can enter the marketplace in a form adapted to exchange, whether as mortgages, contracts, warehouse receipts, promissory notes or share certificates. Commercial legal codes are built on a foundation of such standardized instruments. Many of those instruments, such as land titles and corporate securities, are entered in a land registry or in a corporate share registry governed by legally enforceable rules. Indeed, much of their value derives from this formalization and institutionalization.

338. See Williamson, supra note 4, at 6-25; Hanstad, supra note 10, at 651, 670-686, 702-03; Schwarzwalder, supra note 16, at 190-92 (explaining the importance of the investor's being able to inquire into a purported owner's rights to a piece of land to avoid the risk of buying land that has already been transferred to another investor). 
demnification if, despite all other reasonable risk reduction efforts, they lose their interest in land. ${ }^{339}$

Remaining sections of this Article will discuss briefly ways that legislation might reduce risks to those whose investments involve land. ${ }^{340}$ This Article then will apply to China's land title registration system the recommendations made by Williamson, Schwarzwalder, Prosterman, and Hanstad in their works on land title registration systems. ${ }^{341}$ The remainder of this Article will focus on means of reducing risks with private land title services and insurance contracts that are specifically tailored to the title risks investors in land face in China.

\section{A. Reducing Risks to Land Titles by Legislation and Regulation}

Certainly, the fact that potential consequences of an existing law threaten an owner's or lender's title, does not necessarily indicate the need for legal reform. For example, one risk described above is that the State may reclaim a land use right for a public purpose, paying the holder "appropriate compensation." ${ }^{342}$ In the United States, the same government power is called eminent domain. ${ }^{343}$ In both countries, this law must exist for the greater public good, despite the risk to individual property rights. Another risk to purchasers in both China and the United States is a neighboring property owner's ability to enforce a continuing right of access over another's land. Such neighborhood rights in China ${ }^{344}$ and prescriptive or implied easements in the United States are not recorded in the public land registries. Nevertheless, in both nations, the balancing of different landowners' interests has resulted in law that permits a degree of risk to property purchasers and lenders. Purchasers and investors need to look to other sources of protection against such risks, such as the private contracts of indemnification discussed in section III.C. . $^{345}$

In general, however, a goal of creating a stable rule of law is securing citizens' rights, including their legally recognized property rights. The relationship between policy and law in China historically

339. See supra section I.B.

340. For a discussion of potential changes in Chinese land regulation legislation, see generally RANDOLPH \& LOU, supra note 29.

341. See Williamson, supra note 4; Schwarzwalder, supra note 16; Bledsoe \& Prosterman, supra note 20; Hanstad, supra note 10.

342. See supra section II.D.3.

343. See U.S. Const. amend. V.

344. See supra section II.C.7.

345. See infra section III. 
has contributed to investors' insecurity about the effectiveness of China's laws and legal institutions. ${ }^{346}$ In addition to clarifying laws through the enactment of legislation and the adoption of implementing regulations, the government at all levels must make a consistent effort not only to enforce the law, but also to follow it. Only then can investors be secure that the law on which they rely will prevail. ${ }^{347}$

Investors need to know exactly what laws and regulations affect the land they are acquiring or developing, so that they can be assured of being able to utilize the land in accordance with their investment purposes. The discussion in section II, of uncertainties and ambiguities consequent to existing laws, suggests places to begin. For example, as discussed in section II.C.11, assessed and unpaid taxes are a risk to purchasers, lessees, lenders, and other investors' acquiring interests in land use rights and buildings. The applicability of various Chinese tax laws to various properties, and the consequences of delinquency in payment should be clarified. The law also should make tax records publicly available so that purchasers, lenders, and other investors can verify whether all tax obligations have been fulfilled. Another uncertainty noted repeatedly in section II is the failure of many laws and regulations to specify both time limitations for compliance and the consequences of noncompliance. Much uncertainty could be resolved if those laws and regulations were amended to include time limitations, deadlines, and clearly stated consequences of noncompliance.

Professors Randolph and Lou, in their book Chinese Real Estate Law, make several other suggestions. ${ }^{348}$ For example, they recommend that Chinese lawmakers clarify mortgage laws to permit resale of mortgaged property without a mortgagee's prior consent where the mortgage is to be wholly paid from the proceeds of the sale. ${ }^{349}$ They also recommend legal reform to remove the requirement for mortgagee approval of a sale, so that absence of mortgagee approval does not make the transfer of the property invalid. ${ }^{350}$ They propose instead

\footnotetext{
346. Bledsoe \& Prosterman, supra note 20, at 1.

347. See Williamson, supra note 4 , at 9 , stating:

A land administration infrastructure requires a legal framework which enforces the rule of law. Such a framework requires not only good laws but also legal institutions, professionals and government officials who are versed in the law, and a justice system which enforces the law. Such a legal framework is essential to ensure that land holders are secure in their occupation, they are not dispossessed without due process and compensation, and the land market can function with confidence and security.

348. RANDOLPH \& LOU, supra note 29, at 291.

349. Id.

350. $I d$.
} 
that mortgagees simply add a clause to the mortgage instrument making the loan due on sale. ${ }^{351}$

Investors also need assurance that laws and regulations in existence when their investments were made will be enforced and not ignored or retrospectively changed. The Chinese Communist Party should not have to issue policy circulars imploring local governments to conform to existing laws. ${ }^{352}$ A recent study by David Bledsoe and Roy Prosterman gives several examples of laws mandating the granting of land use rights that local governments are not following. ${ }^{353}$ They recommend implementing regulations and model contracts to clarify the laws and the rights and obligations of those persons granted interests in land. They also recommend recognizing private causes of action so that citizens can require governmental entities to follow and enforce existing laws and regulations. ${ }^{354}$

351. Id.

352. Bledsoe \& Prosterman, supra note 20, at 2. The cited circular declares that all levels of government are to manage state affairs by use of the law:

In contrast to most market economies ... policies in China are often written (though rarely widely published) and carry significant authoritative weight without a corresponding implementing law. CCP policies (in the form of directives or statements) are the foundation of Chinese law. The CCP initiates political, economic, and social change in China through the issue of policy directives. The August 1997 Notice Concerning Further Stabilizing and Perfecting the Rural Land Contracting Relationship serves as an example. This policy stood alone for almost a year before subsequent legislation was passed to put the policy's intent into law .... The relationship between Chinese law and policy has not served to prompt the preeminence of the rule of law. China's relatively rapid development of economic reform policy has meant that, particularly in the environment of fledgling law-drafting and legal engineering skills, law lags behind policy. Therefore, policies are sometimes implemented without any legal basis, and sometimes existing laws are ignored, shunted aside, or bent when new policies conflict with the existing laws .... The distinction between Chinese law and policy has also been blurred because the supremacy of state law (relative to CCP policy declarations) has not been firmly established in theory nor significantly observed in practice. Policy is often viewed as being supreme to law, and, in some cases, sufficient by itself as a tool of its own implementation.

Despite the uncertain relationship between law and policy in China and the use of policy as a tool for its own implementation, it is clear that the rule of law is recognized by the CCP and state government as an effective way to create policy outcomes. This recognition is shown by the use of the rule of law to attract foreign investment to China. Foreign investors seek the risk-reducing characteristics that make up the rule of law. Legal authority, certainty, generality, congruity, enforcement, and a viable legal profession are all prerequisites to managing investment risk.

$I d$. at 5-7 (footnotes omitted).

353. Id. at 1-11. In addition, Bledsoe \& Prosterman note the following:

To serve as an effective tool of Chinese policy implementation, the law must assume a place of supremacy and serve as the ultimate authority in ... transactions, mandates, and prohibitions .... Greater clarity, specificity, and comprehensiveness in the laws and regulations would reduce the necessary interpretation .... Localism can undermine the rule of law and create insecurity, unless the laws are enforced at all levels by the government and by citizens.

Id. at 9 .

354. Id. at $1-11$. 
Consistent recognition and enforcement of the preeminence of the law must occur contemporaneously with solidifying the land title registration system. Registration of land rights will have little impact on investment in, economic development of, and social stability of a country without consistent recognition and enforcement of those rights. ${ }^{355}$

\section{B. Increasing Land Title Security with Improvements to China's Land Title Registration System}

China needs to increase the security its land registration system provides by making it as conclusive, reliable, accessible, efficient, and economical as possible. As discussed in section II.A., a land registry is intended to establish the rights to each parcel of real estate. A legal interest in land is not created or transferred until the registrar determines the current state of title and enters it in the land registry. ${ }^{356}$ With a few exceptions, rights not reflected in the register are not to be recognized, even if legitimate. ${ }^{357}$ To be conclusive and reliable, a land registry must be complete. To be complete, a land title registration system must be accessible, efficient, and inexpensive so as to avoid disincentives for its use..$^{358}$ This section will suggest ways to make

355. Williamson, supra note 4, at 20 (making the same comment as to inability of legally insecure land rights to impact the environmental management of a country).

356. The land register both states the identity of the owners of the title and lists all easements, liens, mortgages, leases, covenants, and other encumbrances against the title. If encumbrances are added or removed, notations are made in the register. An owner who transfers land brings the contract or deed to the registry and the registrar makes a new entry on the register in the name of the new owner. In systems that use certificates, the registrar issues a new certificate. The registrar maintains files or books containing the originals or copies of all documents referred to on the land register so an examiner can review them. The files or books usually are indexed by tract of land, permitting easy location of all instruments affecting title to that tract, regardless of who is the grantor or grantee of the property interest. However, a prospective purchaser or lender wanting to learn the status of rights to a tract of land only needs to inspect the current land register. Schwarzwalder, supra note 16, at 167.

357. Nevertheless, in Canada and England this is truer in theory than in fact, and courts recognize many exceptions in the interests of fairness and equity.

358. See Williamson, supra note 4, at 15, 27 (quoting the United Nations International Federation of Surveyors Bogor Declaration on Cadastral Reform):

The success of a cadastral or land administration system is not dependent on its legal or technical sophistication, but whether it protects land rights adequately and permits

those rights to be traded. . . . efficiently, simply, quickly, securely[,] and at low cost.

However, if the resources are not available to keep the cadastral system up-to-date then there is little justification for its establishment.

See also Schwarzwalder, supra note 16, at 165 (arguing that a functioning land registration system protects land rights by removing procedural obstacles that can hinder the trading of the rights). 
China's land title registration system more reliable, accessible, efficient, and inexpensive.

China's current registration procedures contain many of the components that experts recommend. The registration process includes the following: (1) a land registration application form; (2) registry officials' obtaining a survey of the land; (3) registry officials' examining the title to the land and adjudicating or mediating competing claims; (4) completion of a land registration card for each legal person with an interest in the land and placement of it in the land registration book; and (5) issuance of a land title certificate to the applicant. ${ }^{359}$ When a registered land use right is subsequently transferred, when any changes are made to the name of the land user, or when a previous land registration is to be cancelled, a new registration is made. ${ }^{360}$ If an applicant claims to have lost a land use rights certificate, then public notice and a comment period will be given before issuance of a new certificate. ${ }^{361}$ The LAB is responsible for settling disputes over land use rights by mediating disputes and registering the results. ${ }^{362}$ Further, China is among those countries in which the registry office is financially responsible for financial loss caused by its negligent registration of an interest. ${ }^{363}$

At least theoretically, the local LAB's book of land registration cards should be indexed by tract of land. ${ }^{364}$ Each LAB office should file the following: the land registration application forms received; the documents submitted as evidence of legal rights in the land with each registration application; the land registration approval form; the land registration book composed of all the land registration cards; receipts for land use rights certificates; and any other agreements or documents made for deciding titles to land. ${ }^{365}$ Chinese law also provides

359. Rules on Land Reg, ch. II, arts. 10-19, supra note 31, at 2124-26; RANDOLPH \& LOU, supra note 29, at 164 .

360. Rules on Land Reg, chs. IV, V, supra note 31, at 2129-33.

361. Id.

362. Land Law, ch. 2, art. 16, supra note 29, at 2145-46; Rules on Land Reg, ch. II, art. 17, supra note 31, at 2126. "The main principles employed in this work are "to respect history, but take into account the current situation for the benefit of social stability and unity." PEI, supra note 29 , at 110 .

363. The office will be liable for the "direct economic consequences" of its error. These do not include the owner's "expectation damages," even those that might be regarded as "reasonably foreseeable." RANDOLPH \& LOU, supra note 29, at 171.

364. Rules on Land Reg., ch. VII, art. 60, supra note 31, at 2135.

365. Rules on Land Reg., ch. VII, art. 59, supra note 31, at 2135. 
for a national cadaster ${ }^{366}$ for purposes of taxation and land use planning.

Despite theory, in some locations the organization of the land registry records renders the records inaccessible in fact. ${ }^{367}$ Furthermore, public inspection reportedly is not permitted in some locations. In 1996, Land Registration Rules changed the pre-existing policy of open public inspection. ${ }^{368}$ These Rules required parties wishing to inspect the registration records, including potential transferees and mortgagees, to apply for permission in writing. ${ }^{369}$ The 1998 Implementing Regulations of the Land Administration Law restated the previously existing policy that records should be available for public inspection. $^{370}$ Yet, it is not clear whether permission will always be granted, particularly to foreigners, or whether times permitted for inspection will be reasonable..$^{371}$ "[R]egular and effective access to the registration records may not be a practical reality in some areas unless the party seeking such access has guanxi [a connection]." ${ }^{, 72}$ Reportedly, it is often difficult even for lawyers to inspect the register. ${ }^{373}$ A fee charged for access to the registry records also may inhibit use. $^{374}$ If access is expensive or difficult, transferees may choose to rely on seeing a transferor's certificate of registration rather than verifying the status of title on the card at the land registry office. This is a risk to the transferee since the certificate does not create the title as the registration card does.

366. The local LAB surveys the locality, utility, quality, quantity and legal rights as to each parcel of land and categorizes it as to natural and social-economic character. PEI, supra note 29, at 113; see generally Hanstad, supra note 10, at 651:

A cadastre is a systematically organized database of property dates within a certain jurisdiction.... Although cadastres were originally established for land taxation purposes, in many countries they later were used for land registration purposes. When a cadastre is used for land tax purposes, it is a 'fiscal cadastre;' when it is used for land registration purposes, it is a 'legal cadastre.' It is important to note, however, that a cadastre, or even a cadastral survey, is not a requirement for a land registration system.

367. RANDOLPH \& LOU, supra note 29, at 166.

368. Id. at $165-66$.

369. Id. at 166; Clarke \& Howson, supra note 29, at 15; Developing P.R.C. Property and Real Estate Law: Revised Land Registration Rules, 18 No. 4 E. AsIAN EXECUTIVE REP., 15 (Apr. 15, 1996).

370. Implementing Rules for the Law of the People's Republic of China on Land Administration, ch. II, art. 3 (State Council Dec. 27, 1998), translated in WAN ET AL., supra note 29, at 2084 .

371. RANDOLPH \& LOU, supra note 29, at 166.

372. Id.; see also Godwin, supra note 268, at 121-22 (arguing that Art. 45 of the PRC Security Law providing for inspections of the registration department is more theory than practice).

373. Godwin, supra note 268, at 122.

374. $I d$. 
The Chinese government needs to find ways to ensure easy access to well-organized registration records. ${ }^{375}$ The records' being open to public inspection will permit transferees to see that the registry's official card matches the transferor's representation of the status of title. The risk of proceeding with planning, financing, and purchase is great if the transferee cannot know that the title is what the transferor purports until after the transferee completes the transaction and has its own application for land use rights registration accepted or declined. The public also will be more confident in the accuracy of the registry's conclusions as to the proper holder of title and less worried about corruption or political favoritism if both the registry book and copies of right-establishing documents are open to public inspection. $^{376}$

Timeliness of access is also important. If immediate access is not possible due to administrative constraints, access should be made available as soon as possible after application. ${ }^{377}$ A few days' delay may be tolerable during the early stages of development of a nation's registration system, since the level of administrative capacity and expertise within the registry office may require more time to locate and provide information accurately. ${ }^{378}$ This delay should not significantly deter land registration. However, the goal should be to reduce the time required to provide information to the public. Procedures in a registration or titling law that cause unnecessary delays in the process must be avoided. ${ }^{379}$ Regulations governing registration should estab-

375. Id.

376. "If access is limited, the long-term integrity of the land registry system may be threatened. Moreover, the registry's usefulness as a source of land market information remains unmet if public access is limited." Schwarzwalder, supra note 16, at 175 (discussing public access to land registration records in Eastern European countries).

377. Id. at 176 (considering timeliness of access to land registration records in Eastern European nations).

378. Id.

379. In Romania, for example, alienation rights under the new land law are tied to possession of legal title, so delays in title distribution have prevented further transactions. Id. at 171. Slow registration and titling in the Baltic countries has been identified as an obstacle to the development of well-functioning land markets in those countries. Id. In Hungary, average delays of six months in the land registration process have heightened uncertainty surrounding real estate transactions, instead of providing security. Id. See also DE Soto, The OTHER PATH, supra note 5, at 136-39 (finding that acquiring legal ownership of an existing urban home in Peru required an adjudication of state land and an average of forty-three months and involved up to six different state departments). "Obviously, one reason people invade land and build their homes outside the law is that the legal channel established for gaining access to land for housing is severely restricted." Id. at 139. 
lish time limits for actions by registration officials, with penalties for failure to meet such time limits. ${ }^{380}$

China's land registry system also could be more efficient, accessible, inexpensive, and reliable if all rights, restrictions and responsibilities with regard to land were registered in one place. ${ }^{381}$ China's current dual system, comprised of one system for land registration and a separate system for building ownership and lease registration, should be consolidated. Otherwise, transfers of land use rights will require two separate registrations. ${ }^{382}$ The 1994 Law on Urban Real Estate Administration authorized provincial governments to consolidate the registration and certificate issuance system within their own jurisdictions. ${ }^{383}$ In some areas, such as Shanghai and Shenzhen, one government agency, the Municipal Building and Land Bureau, now issues a uniform certificate for both interests. ${ }^{384}$ This consolidation should proceed throughout the country to reduce the risk that a transferee will err and fail to make the second required registration and to save time and expense in registration. Other offices that handle matters that can result in claims against land also should work systematically with the LAB, so that transfers or successions by inheritance handled by courts or local authorities and tax liens entered against land by taxing authorities are all entered in the land registry.

China's land title registration system is also labor-intensive and expensive. Training and staffing a land registry office in each county for the many procedures required to register each parcel of land in a timely manner means employing many persons. ${ }^{385}$ Obtaining accurate

380. Schwarzwalder, supra note 16 , at 187.

381. As discussed supra in section II.D.1, the 1996 Land Registration Rules do not specify the exact location in which registry records will be maintained. RANDOLPH \& LOU, supra note 29, at 166. "The Rules stipulate that the registry will be at the county level or above, without clarifying what interests are to be recorded where." Id. In a county where a county level registry office has not yet been opened, registration of interests in land in that county should occur at a land registry office that will be maintained at a higher level of government for several counties. Yet, it creates concern that checking title at the county level may not reveal competing interests registered at the Provincial level, etc.

382. Urban Real Estate Law, ch. 5, art. 60, supra note 33, at 2073.

383. Id. at 2074.

384. RANDOLPH \& LOU, supra note 29 , at 163.

385. A 1972 United Nations report identified several general needs for training that may provide guidance. Schwarzwalder, supra note 16, at 175. First, policy makers will need some training in the fundamental aspects of a land title registration system. Second, high-level administrative and professional staff likely should be sent to observe land title registration systems in other countries. Third, professional personnel will need to receive training in the form of periodic seminars to keep up with current developments. In addition to the expense for training cited by the United Nations, another expense will be training of professional personnel and staff 
land descriptions and adjudicating the title for each initial registration is very time-consuming and costly. However, reducing the number of employees to reduce expenses would slow the registration process. Computerizing the registration system would improve reliability and efficiency of indexing, but requires a large initial investment and also can make corruption even more difficult to uncover. Manual systems of ledgers or cards were successfully utilized in other countries before computerization. If China's land registration system is to remain state-run, a manual system may be optimal for the present.

Another cost is that the government bears the expense of guaranteeing the rights to buildings as shown in the register. ${ }^{386}$ Even if the registrar negligently makes an error, vesting title in the wrong person or failing to include a valid encumbrance, the register is still legally binding. The victim of such a mistake loses her interest in the land, but she may claim monetary compensation from the land registry. ${ }^{387}$

If the State tries to cover all the preceding costs of registration with fees charged for registering interests, the cost of registration may become a hindrance. The best way to reduce the expense to the government of land title registration may be to eventually privatize the land registry offices at the local level. Privatization would leave the government responsible only for the expense of adjudicating the initial title to each parcel and for maintaining just one central office per province. Another solution that some experts recommend is to place less emphasis on surveys, permit simple descriptions of boundaries, and recognize a concept like adverse possession to the extent of making the boundaries of parcels of land as occupied their actual, legal boundaries. ${ }^{388}$ If commercial purchasers, lenders, or investors re-

to understand and recognize interests the law permits in land, encumbrances, title defects, and risks, as well as means to obtain releases of claims or otherwise cure or resolve title disputes and problems. Id. Fourth, the general public must be educated about the need to register in order to attain legal title and to use the registry to determine who owns land before accepting a transfer of an interest therein. See also Hanstad, supra note 10, at 686.

386. See generally Schwarzwalder, supra note 16, at 168 (stating that most public land title registration systems share this feature and expense).

387. RANDOLPH \& LOU, supra note 29 , at 171.

388. See generally id. at 177 (noting that Chinese law does not have the concept of adverse possession in a form as developed as the common law); Williamson, supra note 4 , at 12 . The different practices of describing land parcels for registration purposes in different countries are discussed in Hanstad, supra note 10, at 677. See also Schwarzwalder, supra note 16, at 177 (reasoning that, in Australia under the Torrens system and in the U.S. recordation system, sellers of land are not normally obligated to supply purchasers with surveys of the land being transferred. In these countries, a survey only is required when the purchaser insists because the seller is unable to provide a sufficient means of identifying the land parcel otherwise). Schwarzwalder also notes that in Russia, the Land Registration Law does not require a specific, high standard for 
quest a more exact establishment of boundaries, they may bear the expense of the survey, as is the practice in Australia and the United States. A third recommendation is that to promote the most comprehensive registration of interests, fees should be charged on a slidingscale based on a percentage of the value of the interest being transferred, rather than a flat registration fee per document. ${ }^{389}$

No matter how accessible, efficient, and economical a land registry system is, "overriding interests" will continue to pose a risk to investors. $^{390}$ A land registry does not reveal interests in land that are created by operation of law rather than by instrument of conveyance, even though the registered title may be subject to such legally created interests. "O19 "Overriding interests" include liabilities that arise under statute such as land taxes, land use regulations, certain public easements, and the government's retained interest that permits termination of a transferee's land use right in the public interest. ${ }^{392}$ A second category of "overriding interests" includes rights that might be ascertained by inspection of the land or by inquiry of persons in possession, like residential leases and China's neighborhood rights. ${ }^{393}$ Purchasers and investors must inquire into laws recognizing matters such as servitudes, covenants, and rights of conservation or preservation and facts that implicate them before investing. ${ }^{394}$ Laws preserving such rights against land purchasers must be as clear as possible; lack of clarity about whether unregistered claims against land may be valid can undermine the system and inhibit investment in land. ${ }^{395}$ The risk of "overriding interests" that are not reflected in the public land title registry is one reason that investment analysts have begun to recom-

\footnotetext{
land descriptions, but allows for registration of a land parcel if a layout of the parcel is submitted that contains a "detailed description of the boundaries." Id. at 178. The "Draft Registration Law" of the Kyrgyz Republic provides another example of land description requirements that have a low initial standard, but contain procedures for adding more detailed descriptions where necessary. "[T]he draft law allows the boundaries of immovable property units to be either fixed or approximate." Id. Either the registry office of the holder of rights can ask for a topographic survey of boundaries if they deem it necessary. Id.

389. Schwarzwalder, supra note 16 , at 172.

390. Id. at 185 .

391. The interests that may defeat the registered title reportedly are fewer than with the United States' record system.

392. See supra section II.C.3.

393. See supra section II.C.7.

394. Schwarzwalder, supra note 16 , at 185 .

395. Id.
} 
mend private title insurance when investments involve land, even in countries with strong land title registration systems. ${ }^{396}$

\section{Reducing Risks to Investors In China With Private Land Title Services and Land Use Rights Insurance}

While legislation and improvements to China's land registration system could alleviate some of the risks to investors described in section II, the slowness of the political process and expense to the government prevent reliance on them for much additional security. The use of private risk reduction services and land use rights insurance may be a more realistic and rapid means of securing investments in land in China.

Additionally, even if China amends and clarifies its "rights in rem" laws and optimizes its land registration system, investment analysts may not give their highest ratings to investments involving land, unless insurance of the title or lien is available as a credit enhancement. ${ }^{397}$ As discussed in section I.B., analysts have recommended title insurance on mortgage-backed securities even in countries with conclusive land registration systems on the basis that title insurance offers lenders more complete risk protection than can the traditional due diligence provided by a solicitor's examining the status of title. ${ }^{398}$

At least as to commercial properties, to ensure that purchasers, lessees, and lenders will be able to realize their investment-backed expectations, a private insurer of land use rights in China should provide risk elimination services in addition to indemnification against

396. See infra sections I.B. and III.A.3.

397. See discussion infra section I.B.

398. Michaux \& Gibson, supra note 27. In particular, Standard \& Poor's analysts advise investors in Australian and New Zealand residential mortgage-backed securities:

The title insurer insures an item that traditionally may have been checked physically and identified by a solicitor. The discovery of such an item may render the mortgage ineligible for inclusion in an RMBS portfolio. However, where the mortgage is originated with reliance on title insurance, the mortgage may be included in the portfolio, with the risk assumed by the title insurer, whether or not the title insurer had identified the item in its due diligence process. The scope of searches and enquiries conducted by solicitors is likely to vary between RMBS programs and often may be less stringent than the title insurer's process ... Investors rely on the insurer's financial capacity to pay a claim. Whether this capacity is an enhancement for investors depends on the relative financial strength of the title insurer, as opposed to the solicitors and others, who conduct the traditional due diligence process.

Id. In The Other Path, economist Hernando de Soto notes that in addition to registration of legal land titles in a public registration system, private insurance is necessary to provide the security and credit required for investment in housing and other activities in order to strengthen rights to real estate and improve the land title system in Peru. De Soto, The Other Path, supra note 5 , at 260 . 
losses. ${ }^{399}$ The model would be a hybrid of American title insurance and the new Western European title insurance. As to home mortgage liens, if China's registration system becomes sufficiently reliable, an insurance model with a greater casualty element might become appropriate, but that topic is beyond the scope of this paper. ${ }^{400}$

Title insurance in the United States has basic similarities to other forms of insurance. Yet, due to its origins in the context of real property transactions and the financing thereof, American title insurance possesses several unique characteristics. ${ }^{401}$ The distinctive features of American title insurance primarily relate to its being structured on the concept of risk elimination, rather than mere risk assumption. ${ }^{402}$ An American title insurance agent does more than sell title insurance for title insurance underwriters. For this reason, large American title insurance agencies often have attorneys on their staffs and individual title insurance agents usually are attorneys. Upon receiving an application for title insurance, the American title insurance agent first searches the public records and examines all the instruments affecting title to the parcel of land to determine the status of the title and any

399. Because lenders today can expedite loan approval, the pressure is on to speed title assurance so that the transaction can be completed. Some title insurance companies attempt to skip the title search and examination of instruments in the chain of title, since that is the timeconsuming part of the process. They rush right to issuing a title insurance policy. If permitted, this removes the risk elimination aspect of the title search and examination and insurance process, and investors are not made as secure as with traditional title insurance. They receive the contract of indemnity, but that is not a substitute for a title search because the developer and investor would prefer to keep the land, rather than receive a minimal amount of cash if their title proves to be defective. See generally PALOMAR, supra note 21, §§ 1.04[1] \& 18.06[4].

400. To secure home mortgage liens, an appropriate model might be mortgage impairment insurance that covers losses resulting from borrowers' defaults, including losses due to title defects. These policies are sold to mortgage lenders to cover an entire pool of residential mortgage loans before the pool is sold into the secondary mortgage market. Information that at least one American mortgage impairment insurer now includes loss resulting from title defects within its coverage, and that Standard \& Poor's has approved this product, came to the author the week that this publication was to go to press. While it was too late to consider the idea in this Article, the author will examine whether the combination of a working registration system with mortgage impairment insurance covering title defects on a casualty basis might provide sufficient credit enhancement for investors in the secondary mortgage market. See PALOMAR, supra note $21, \S 1.01[4][\mathrm{c}]$.

401. PALOMAR, supra note 21, §1.04[1]; see also, JOYCE PALOMAR, chapter entitled "Title Assurance of Property Outside the United States," in TitLE Insurance LAW (Supp. 2002, forthcoming).

402. Title insurance in America traditionally was not issued on a casualty basis and has excluded or excepted from coverage other risks that are not discoverable in a search of the public records, though demand and competition recently have prompted both the addition of some casualty coverage to homeowners policies and some efforts to insure refinanced mortgage liens on a casualty basis. PALOMAR supra note 21, §1.05; Old Republic National inadvertently announces no-search policy, THE TITLE REPORT, Dec. 4, 2000, at 1, col. 2. 
defects in or encumbrances thereon. The title agent then may work with the transferor and transferee to accomplish documentation or legal action needed to eliminate many discovered title defects and encumbrances. In fact, traditionally more than ninety percent of the premium dollar for title insurance in the United States is spent on determining the status of title and eliminating title risks before the purchaser, lessee, or lender accepts the title and closes the transaction. ${ }^{403}$ Unlike auto, life, or health insurance, the American title insurance policy does not cover title defects that originate after the policy is issued. ${ }^{404}$ Instead, it only protects the insured from the assertion, subsequent to the date the policy is issued, of liens, encumbrances, or other title defects that existed prior to the policy date. ${ }^{405}$ Thus, the title agent's discovery and elimination of pre-existing encumbrances and title problems not only protects the insured's investment by preventing future claims, but also gives the underwriter the opportunity to reduce and control most of its risk.

While American title insurance agents help to eliminate risks, their title insurance policies exclude most risks that the agents cannot discover from coverage, rather than covering them on a casualty basis. Standard American owners and lenders' title insurance policies, in preprinted general exclusions, exclude loss resulting from any of the following: (1) building, zoning, land use, and other governmental regulations, including exercises of governmental police power, ${ }^{406}$ eminent domain, and environmental laws; ${ }^{407}$ (2) a lender's violation of state "Doing Business" laws ${ }^{408}$ or usury laws; ${ }^{409}$ (3) mechanics' liens, ${ }^{410}$ (4) claims based on creditors' rights; ${ }^{411}$ (5) claims of parties in possession not shown in the public records ${ }^{412}$ and easements not of record; ${ }^{413}$ (6) boundary conflicts, encroachments, and other matters that an accurate survey or an inspection of the premises would reveal; (7) encumbrances or title defects first created after the date of the policy; and (8) matters created or suffered by the insured or that were known

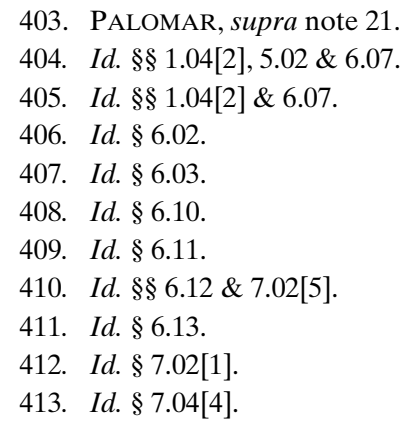


to the insured and not in the public record. ${ }^{414}$ Standard international title insurance policies recently promulgated by American title insurance underwriters ${ }^{415}$ also exclude or except all the preceding undiscoverable matters, plus the following: (1) resumption of rights under the laws of the country in which the land is located, unless notice was of record at the policy date; ${ }^{416}(2)$ water rights and claims to natural resources; (3) claims both (a) by third parties outside the country where the land is located and (b) relating to the interpretation or enforcement of the policy by a court or tribunal other than in the state where the insurer is domiciled; ${ }^{417}$ and (4) war, insurrection, civil unrest, act of the public enemy, epidemic, governmental restriction, nationalization, act of God, "or other similar causes.",418

Many of the preceding are exactly the risks that investors in China most desire security against. When insuring titles to land in the United States, the American policies still give value despite all these exclusions because they do cover undiscoverable risks that result from the design of the grantor-grantee indices used in the majority of states' public land records. The American policies would not give that value in China, however, because China's registration system utilizes a tract index and does not pose that set of risks. Additionally, when American title insurers' policies are issued on land in the United States, they give value by covering the risk that an instrument in the record chain of title was legally insufficient to transfer title to the record title holder because of facts that are not apparent on the face of the instrument. Such facts may include fraud, forgery, or duress in the execution of instruments affecting title to the insured land; false impersonation of the landowner; execution of instruments by a minor or an incompetent person; heirs not disclosed in the public records who have an interest in the land; wills not discovered before

414. Id. § 7.02[2].

415. See the standard "International Policy" promulgated in 1999 by First American Title Insurance Company, one of the United States' five largest title insurance underwriters and the Loan Policy of Title Insurance on Mexico Land 1992 promulgated by Stewart Title Guaranty Company (on file with the Duke Journal of Comparative and International Law).

416. Id.

417. See the standard "International Policy" promulgated in 1999 by First American Title Insurance Company, supra note 415.

418. Id. First American's 1999 International Policy form also generally "excepts" from coverage both (1) taxes or assessments by any taxing authority and (2) riparian rights, changes in watercourses, submerged land or land that was formerly submerged, or filled or reclaimed lands. See also Owners and Loan Policies of Title Insurance on Mexico Land 1992 promulgated by Stewart Title Guaranty Company (on file with the Duke Journal of Comparative and International Law). 
purported devisees conveyed their supposed interests in the title; improper notice of judicial proceedings given to those with interests in the land; deeds executed under powers of attorney subsequently declared to be invalid; undisclosed marriages and divorces which result in claims of marital property rights; and copyists' and indexing errors. ${ }^{419}$ Again, however, these matters are not a risk in China because a registered title is conclusive. An adverse claim should not ever succeed against the registered title; therefore, if a land use rights insurance policy merely insures that title as shown in the land registry, then an adverse claim will not ever succeed against the insured title. With little chance of succeeding with an attack on the insured title itself, an adverse claimant would be limited to seeking monetary indemnification either from the party who committed the fraud or forgery, or from registry officials, if they negligently registered a fraudulent land use right. In most registration systems, the only exceptions to the conclusiveness of the title as registered are the "overriding interests" described in section III.B., but all these are already excluded from the coverage of the American policies by pre-printed exclusions. Furthermore, if an insured land use rights holder complains that a subsequent fraudulent registration has deprived the insured of its land use right, such claim also would not be covered because the American title insurance policies exclude title defects created after the policy was issued.

Thus, standard American title insurance policies that were designed to insure risks in the United States recording system give no real coverage of the risks that investors in land use rights face in China. In comparison, one underwriter in Western Europe recently began to offer title insurance in the United Kingdom, France, Spain, and Italy. This form of title insurance was designed in a country with a registration system to insure registered titles. ${ }^{420}$ It normally covers both unknown risks and many discovered risks on a casualty basis without the number of pre-printed exclusions and individual exceptions that appear in American title insurance policies. ${ }^{421}$ For example, it expressly covers restrictive covenants, rights of parties in possession, undocumented rights of way, and other risks that American policies usually except from coverage. ${ }^{422}$ Nevertheless, while this

419. PALOMAR, supra note $21, \S 1.05$.

420. John Webster, Title Insurance Set for Growth in the UK, available at http://www. insurance-first.com/Placed\%20stories/July/27/title.htm. (last visited Nov. 23, 2001).

421. $I d$.

422. See id. 
Western European title insurance policy has the strength of covering more risks on a casualty basis than the American policy forms, it does not include the risk elimination and claim prevention features of American title insurance. Because these Western European countries' land registries are reliable and conclusive, no attorney or title insurance agent examines the documents in the registry file for encumbrances, works with the purchaser or lender to eliminate risks before the closing of the transaction or otherwise underwrites individual titles. $^{423}$ Instead, the title insurer merely has a solicitor (1) check that the description of the applicants, the property, and any existing charges corresponds to the showing in the land registry; (2) send the instruments of conveyance to the parties to sign and return; and (3) obtain clear title reports showing title in the insured from the land registry and land charges registry. ${ }^{424}$

Certainly, neither the Western European form of title insurance nor the American standard policies should simply be transported to and sold in China. If land use rights insurance is offered in China, it should be written to respond to the unique risks to purchasers, lessees, lenders, and other investors extant in China's real property laws and land registration system. Because China's registration system and laws permitting transferable land use rights are so new and untested, the market likely would respond best to a hybrid of American and Western European forms of title insurance. A private title agency or lawyer-agent could, first, improve the land use rights security of investors by reducing many of the risks to purchasers and investors before their transactions are closed. A contract of indemnification or insurance could then protect investors against most of the remaining risks on a casualty basis.

For instance, a land use rights agent or an attorney serving as an agent (collectively, the agent) first would determine the status of a transferor's land use right by examining the registration card at the local land registry office. Because the registration card is conclusive, this may be enough. If the card or other facts suggest prior encumbrance or claims, however, the agent also could ask to examine the registry's file of documents pertaining to the parcel of land. Because of the current possibility of multiple locations where interests might be registered, ${ }^{425}$ the agent would need to perform this examination at both the land registry and the building registry "at the county level

423. See id.

424. Id.

425. See supra section II.A.1. 
and above." ${ }^{426}$ Depending on what the registers reveal, the agent may assist with various actions to clear the land use right of others' claims. For example, if the examination of the register reveals that the land actually is held by allocated land use rights, the agent then can assist in the required conversion to granted land use rights before the transaction is closed, as described supra in section II.D.6.

An attorney or other land use rights agent also could reduce the risks of boundary disputes and inadequate land descriptions considered supra in section II.A. by examining the registration card for the parcel in both the Building Registry and the Land Administration Bureau registry at all governmental levels at which registration could have been made. The agent then might (1) compare the land description of the parcel in the parties' contract to its description in each register; (2) arrange for resolution of any conflicting survey maps; (3) obtain waivers or releases from contiguous property owners as to encroachments of improvements or boundary questions; (4) file in the appropriate registry offices the transferee's application and the instruments of transfer; and then (5) verify the registrar's entry of the transfer on the official registry card with the correct land description and the placement in the registry file of all supporting surveys and documentation. The filing of that documentation in the registry should make the results conclusive as against unfiled claims. ${ }^{427}$ With the risk reduced in the preceding ways, the land use rights insurer then would be able to issue a policy insuring against loss if the property's boundaries are determined to be other than as shown in the LAB and Building Administration registries. If the land use rights agent was unable to eliminate particular land description inadequacies or boundary problems discovered in the agent's title examination, the insurer would decide whether to cover the risk or to except that particular matter from the policy's coverage.

An attorney or land use rights insurance agent could help eliminate the risk both of encroachments and of claims by unregistered

426. Clark \& Howson, supra note 29 , at 15.

427. If the company performed land title services described in the preceding subsection to reduce risks of encroachments, boundary line disputes, and inadequate land descriptions before the closing of the transaction, the filing of that documentation in the registry should make the results conclusive as against other claimants and the insurer would not need the general exception used in American title insurance policies for encroachments, boundary disputes, or rights that would have been disclosed by an accurate survey or an inspection of the premises. See generally PALOMAR, supra note 21, § 7.02[2] (discussing the purpose and construction of standard American title insurance policies' general exception for matters that would have been disclosed by an accurate survey or inspection of the premises). 
tenants, described in section II.C.4, by having the transferee ascertain what rights are claimed by anyone in possession of the land. If the occupant is a tenant whose lease is to expire before the transfer, the agent could prepare a waiver of the right of first refusal that Chinese law affords to existing tenants. A land use rights insurer would assume some risk in covering claims of parties in possession, ${ }^{428}$ because recent Chinese statutes have utilized possession to resolve boundary disputes and because Chinese Civil Law might apply the doctrine of laches to either estop a title certificate holder from ejecting a longtime possessor of the property or require the certificate holder to pay the possessor for the value of improvements. ${ }^{429}$ So long as Chinese law does not generally recognize the concept of adverse possession, however, the risk of successful claims from parties in possession probably is small and insurable. If China recognizes adverse possession, the insurer's risk will increase.

An agent also could obtain documentation to reduce risks discussed in section II.C. from intricacies of China's laws and regulations. For example, regarding limitations on use pursuant to zoning regulations and land use plans, as discussed in section II.C.1, an agent might determine that the investor's intended use will comply with all the plans and regulations that are applicable on the date the land use right is acquired. ${ }^{40}$ Upon such proof, the land use rights insurer may agree to indemnify the investor if the use described in the policy was not permitted by the land use plans and zoning regulations in force on the date the policy was issued. ${ }^{431}$

An agent could advise lessees that under current law they must obtain separate leases of the land use right and the building. The

428. This is another matter generally excepted from some American title insurance policies. See generally id. § 7.02[1] (discussing the purpose and construction of standard American title insurance policies' general exception for rights of parties in possession). For an additional fee, title insurers issue extended coverage policies covering that risk for lenders and owners in the United States.

429. See supra section II.B.

430. Title insurance underwriters insuring land titles in the United States will give this sort of protection if the applicant pays an additional fee for a special zoning endorsement. PALOMAR, supra note $21, \S \S 6.02 \& 9.05$ \& Appendices O1, O2 \& O3. Otherwise, American title agencies do not research zoning laws and land use regulations applicable to a parcel, since such matters are excluded from the coverage of standard American title insurance policies. Id. $\S 6.02$. Zoning and land use laws and regulations also are excluded from the coverage offered in the standard international title insurance policies that some American title insurance underwriters have developed. See infra section III for discussion of the inadequacies of these policies for investors in China.

431. See id. 
agent then could register the leases at the Land Administration Bureau's registry and the Building Administration registry, respectively. The agency also can ascertain from those registries that a proposed lease is not of a longer term than the land use right it encumbers. ${ }^{432}$ This would enable the underwriter to insure that no portion of the lease term is invalid on the basis that it exceeds the term of the land use right.

Further, an agent could reduce the risk that a transfer of land use rights might subsequently be avoided because preconditions to transfer were not satisfied, resolving concerns raised supra in section II.D.1. The agent could seek (1) certification from the government that the necessary percentage of completion of improvements has occurred; (2) an agreement from the transferor to indemnify the transferee if more work needs to be done to meet the required percentage of completion of improvements; or (3) the guaranteed opinion of a local real estate expert that the required percentage of development has been completed. After reducing the risk by means of these proofs, an insurer then could indemnify investors if loss occurs because the government determines that a precondition to the transfer of the land use right was not met.

The agent could reduce the risks to investors in housing developments discussed in section II.D.1 by obtaining the proofs in the preceding paragraph, plus a copy of the zoning license and presale permit. The agent also would examine the registry to ascertain whether the housing is co-owned by the transferors' work unit or whether the transferors purchased their rights to housing either from work units or at subsidized prices. The agent could obtain a copy of the approval for the transfer from the local housing administration and the written consents of the adults who live in the housing. ${ }^{433}$ If the housing were co-owned by a work unit, the agent would obtain a written statement from the work unit waiving its right of first refusal to buy the housing. ${ }^{434}$ With these assurances, the underwriter would be able to insure both that a presale of a housing development will not be avoided on the basis that it failed to satisfy preconditions for transfer and that it is not subject to rights of a work unit.

Some of the risks involving mortgages and foreclosure identified in section II.D.9 eventually may be reduced by legislation or im-

432. See supra section II.D.1.

433. See discussion supra section II.C.1.

434. Id. 
provements to China's land registration system. In the interim, investors might be encouraged to make mortgage loans in China if land use rights insurance were available to reduce their risks. The land use rights agent could (1) seek certification from the government that the loan and mortgage documents on their face satisfy the equitable standards of China's contract laws; and (2) examine the appropriate registries to assure that the mortgage would have priority over any other registered interests in the land use right or building. The underwriter then could insure the priority of the mortgage over all other registered interests. Of course, like any other insurance, land use rights insurance could not protect against consequences of actions by the lender that the insurer cannot know from the face of the loan and mortgage documents. ${ }^{435}$

Certainly, it is important to decide to what extent a land use rights insurer can insure risks that the land use rights agent cannot discover, reduce, or eliminate. For example, a title agency in China could not discover or reduce the risk of the State subsequently reclaiming transferred land use rights for a public purpose, paying the holder "appropriate compensation" for the loss of the land use right and the improvements to the land. ${ }^{436}$ However, a land use rights insurer may cover the risk of State termination of an insured land use right, because the underwriter can contract in the policy to be subrogated to the insured's right to receive the compensation the State must pay.

A land use rights insurer also could insure against the risk of indexing or filing errors in the registry. The insurance contract would permit the insurer to be subrogated to any rights of the insured to compensation from the registrar's office. ${ }^{437}$ The underwriter could insure against the various "overriding interests" to which Chinese law gives priority despite lack of registration, as discussed in section III.C. above. Some overriding interests, such as the neighborhood rights identified in section II.C.7, may be raised with relative frequency, while others would rarely arise.

435. The risk that the mortgage documents would be unenforceable because they violate Chinese contract laws would be excluded under standard American title insurance policies' exclusions (1) for losses due to laws and (2) for matters created, suffered or assumed by the insured and under similar exclusions in the standard international policies that some American title insurance underwriters have promulgated. See supra section III.C.; PALOMAR, supra note 21 , ch. $6, \S \S 6.02 \& 6.04$.

436. See discussion supra section II.C.3.

437. RANDOLPH \& LOU supra note 29 , at 171. 
A land use rights agent could not discover or eliminate the risk of a subsequent avoidance in bankruptcy of a debtor's pre-bankruptcy contract, transfer, or mortgage involving a land use right or building, as discussed supra in section II.D.10. A land use rights insurer likely would exclude this risk from coverage, because the transferee's loss is due to the debtor's financial problems after the policy date, not to a defect in the transferee's title.

Under the equitable principles of China's contract law, ${ }^{438}$ a land use rights insurer would not be expected to cover matters created, suffered, or agreed to by the insured. Such risks are routinely excluded from all types of insurance policies. Therefore, the policy could not cover the risk, discussed in section II.D.5, of forfeiture of the granted land use right due to the insured's failure to commence or continue the use described in the transfer contract. Once the grantee has met the criteria established by applicable regulations for "commencement" (generally, by investing at least twenty-five percent of the entire projected investment, or, for a developer of a subdivision, by installing the infrastructure, see sections II.D.3 and II.D.5), perhaps the insurer could seek certification from the government that the necessary percentage of completion of improvements exists and then issue an endorsement to the policy. The insurer would not, however, be able to insure against loss resulting from the insured's failure to continue the use in the future.

In this same manner, any insurer of land use rights in China should consider risk-by-risk whether it can give coverage on a casualty basis or whether a risk must be excluded from coverage. Certainly, investors in China would wish to be covered for matters that fall within the category of "political risks." Instead of flatly excluding this risk as the American policies do, an assessment can be made on a case-by-case basis, depending on the amount of the policy, the underwriter's financial strength, and on regulatory authorities in China.

The Chinese government might consider adopting regulations to require that any land use rights insurance actually covers the risks that investors face in China. This can be done by regulating the content of the insurance forms that may be issued in China, as do many states in the United States. ${ }^{439}$ Some states in the United States actually promulgate the forms that may be issued ${ }^{440}$ others mandate that

438. See supra section II.B.7.

439. See generally PALOMAR, supra note 21, ch. 18.

440. Id. 
no insurance policy forms may be issued that have not been filed with and approved by the state regulatory agency. ${ }^{441}$ The latter approach would be preferable for China, at least until regulators become more experienced with land title insurance. As both the law of land use rights in China and the concept of title risks become more generally understood, purchasers, lessees, lenders, and other investors will be able to make their own educated decisions about what title insurance coverage they need.

\section{CONCLUSION}

China has much to gain from increasing the security of title to interests in its land. Secure land titles create access to credit and capital. Legislation to clarify ownership rights and improvements to China's land title registration system can make investors more secure in their ownership interests. Enhancing that basic land title security with the risk reduction services and indemnity contracts that private land use rights insurance could provide, may yield increased foreign investment and a demand for China's mortgage-backed debt in the international securities market.

Private land title agencies that research title risks before transactions are closed, together with an indemnification product, may be the most realistic and rapid means of reducing the many risks that currently concern investors in China. A joint effort between the Chinese government, private title agencies, and insurance underwriters ultimately may be the best means of bringing security, efficiency, reliability, and economy to China's land title system and stimulating real estate investment in China. 